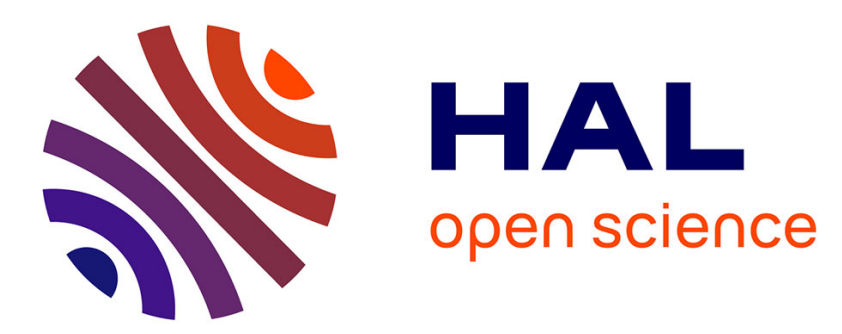

\title{
High-resolution prediction of a major convective period over West Africa
}

Florent Beucher, Jean-Philippe Lafore, Fatima Karbou, Rémy Roca

\section{To cite this version:}

Florent Beucher, Jean-Philippe Lafore, Fatima Karbou, Rémy Roca. High-resolution prediction of a major convective period over West Africa. Quarterly Journal of the Royal Meteorological Society, 2014, 140 (682), pp.1409 - 1425. 10.1002/qj.2225 . hal-03435375

\section{HAL Id: hal-03435375 \\ https://hal.science/hal-03435375}

Submitted on 18 Nov 2021

HAL is a multi-disciplinary open access archive for the deposit and dissemination of scientific research documents, whether they are published or not. The documents may come from teaching and research institutions in France or abroad, or from public or private research centers.
L'archive ouverte pluridisciplinaire HAL, est destinée au dépôt et à la diffusion de documents scientifiques de niveau recherche, publiés ou non, émanant des établissements d'enseignement et de recherche français ou étrangers, des laboratoires publics ou privés. 


\title{
High-resolution prediction of a major convective period over West Africa
}

\author{
Florent Beucher ${ }^{\mathrm{a}}$ Jean-Philippe Lafore $^{\mathrm{b}}$ Fatima Karbou $^{\mathrm{a}}$ and Rémy Roca ${ }^{\mathrm{b}}$ \\ ${ }^{\mathrm{a}}$ CNRM-GAME, Météo-France and CNRS, Toulouse, France \\ ${ }^{\mathrm{b}} \mathrm{OMP} / \mathrm{LEGOS}$, Toulouse, France \\ ${ }^{\star}$ Correspondence to: Florent Beucher, CNRM-GAME, Météo France and CNRS, 42 avenue Gaspard Coriolis, \\ 31057 Toulouse, France. E-mail: florent.beucher@meteo.fr
}

In this article, we evaluate the predictions of the French cloud-resolving model AROME using a set of high-resolution $(5 \mathrm{~km})$ simulations that focus on the well documented African Monsoon Multidisciplinary Analysis (AMMA) period of 23-28 July 2006 over a large domain $\left(0-22^{\circ} \mathrm{N}, 15^{\circ} \mathrm{W}-20^{\circ} \mathrm{E}\right)$. The model skill is assessed against independent Global Positioning System observations of precipitable water and in terms of quantitative precipitation forecasts. As the rain-gauge network is sparse over West Africa, the simulated precipitation fields were compared with data from satellite-based precipitation products (TRMM-3B42). We show that initial and boundary conditions significantly improve the AROME forecasts when the large-scale forcing model (ARPEGE) assimilates surfacesensitive observations from microwave remote-sensing sensors over land surface.

The daily mean AROME precipitation shows a spatial distribution in good agreement with the satellite precipitation estimates. The intertropical convergence zone is correctly reproduced in terms of shape and location but its intensity is broadly overestimated by about $25 \%$. The AROME model is shown to be able to reproduce all regimes, from light rain to the biggest Mesoscale Convective Systems (MCSs). The observations made at the Niamey AMMA supersite allow a detailed evaluation. Near the Niamey AMMA supersite, we show that AROME is able to represent most of the key features of the West African monsoon from the diurnal to synoptic scales. The life cycle of two successive sequences of MCSs associated with an African easterly wave and a deep monsoon burst are well captured by AROME.

Finally, a tracking approach based on the $1 \mathrm{~h}$ accumulated precipitation is applied to both Global Satellite Mapping of Precipitation (GSMaP) satellite estimates and to AROME and ARPEGE forecasts, allowing a good characterization of each MCS and statistics. Contrary to ARPEGE, the AROME MCSs trajectories and lifetimes, and the diurnal cycles of their initiation and dissipation, are in agreement with the GSMaP tracking and previous MCS statistics.

Key Words: cloud-resolving simulation; mesoscale convective system; West African monsoon; African easterly wave; tracking; prediction

Received 6 March 2013; Revised 18 June 2013; Accepted 25 June 2013; Published online in Wiley Online Library

1. Introduction

52 the West African rainfall variability (West African monsoon, WAM) was one of the major aims of the African Monsoon Multidisciplinary Analysis (AMMA: http://www.ammainternational.org/spip.php?rubrique1) project (Redelsperger et al., 2006).

Mesoscale convective systems (MCSs) are responsible for much of the rainfall over West Africa (Omotosho, 1985; Mathon and Laurent, 2001), providing $80 \%$ of the rainfall over the Sahel (Mathon et al., 2002). However, weather and climate models with typical horizontal resolutions between several tens and hundreds of kilometres only partly resolve the largest MCSs and have poor 
skill in forecasting the amount and variability of their associated precipitation (Lebel et al., 2000; Roehrig et al., 2013). African easterly waves (AEWs) are the major synoptic weather systems in the WAM, developing in the vicinity of the midlevel African Easterly Jet over the (Reed et al., 1977; Thorncroft and Hoskins, 1994a, 1994b $\overline{\overline{\bar{a}}}$ d significantly modulating rainfall.

In comparison with midlatitudes, the improvement in numerical weather prediction (NWP) in the Tropics has been very slow even when metrics better suited to low latitudes, characterized by a large Rossby radius (Berry et al., 2006), are used. The skill of an AEW forecast within different operational NWPs is less than $48 \mathrm{~h}$ (Torn, 2010), and the synoptic variability and the coupling between AEWs and precipitation differ considerably among NWP systems. The NWP forecasts are usually unable to generate new AEWs, tending to advect those present in the initial conditions. The basic reasons for such biases and poor skills at short forecast ranges are multiple and depend on the quality of observations (Thorncroft et al., 2003) and the data assimilation (Tompkins et al., 2005; Agusti-Panadera et al., 2010), as well as the models, but also on the level of predictability in West Africa. From this perspective, mesoscale models may be more appropriate than large-scale models for studying and forecasting AEWs, MCSs and their complex interplay.

In the 1990s, technological advances allowed cloud-resolving models (CRMs) to become a powerful tool for the study of MCSs and associated AEWs, especially in West Africa (Diongue et al., 2002). The application of CRMs has been confined to research studies on processes until recently, because of computer power limitations. During the last decade, a new generation of convection-permitting operational models have been developed (WRF in the USA, MetUM LAM in the United Kingdom, AROME in France, and COSMO in Germany, among many others) and are now able to properly resolve the life cycles of MCSs. The initial and boundary conditions appear to significantly control the location of the rainfall over West Africa at the synoptic scale for 1-2 day forecasts (Guichard et al., 2010; Torn, 2010). Some sensitivity studies suggest that the explicit representation of deep convection improves the forecast of AEWs and significantly improves the predicted rainfall distribution, trajectories, and propagation speed of MCSs. Up to now, only a few observed cases of MCS have been simulated with CRM over a period of several days in West Africa (Barthe et al., 2010; Birch et al., 2012; Laing et al., 2012). In the framework of the Cascade UK project, simulations were carried out with a nesting approach (described in Lean et al. (2008)) for 10-day periods (Pearson et al., 2010; Marsham et al., 2011) over large domains (several thousand km) 2 to better understand the interactions between tropical convection and the larger scales.

The skill of such CRM simulations depends strongly on the quality of the large-scale atmospheric and surface fields used to initialize and force simulations. It is still a challenge to attain such accurate simulations over Africa due to the scarcity of observations, the large Rossby radius and the major role played by diabatic and nonlinear processes such as convection. A major legacy of AMMA has been the update and reinforcement of the West African operational network of radiosondes (Parker et al., 2008) completed by a wide range of surface, remotesensing and aircraft observations. It provides a unique set of data documenting the WAM system at different scales. The AMMA programme allowed substantial progress to be made in remotesensing data use and assimilation in tropical regions (Bock et al., 2007; Bauer, 2009; Faccani et al., 2009; Karbou et al., 2010b). It is worth mentioning that a network of six Global Positioning System (GPS) ground stations was developed over West Africa (Figure 1) during the special observing period (SOP). These observations were found very useful for measuring the total column water vapour (TCWV) at different scales (Bock et al., 2007) and for evaluating NWP analyses and forecasts.

The present study focuses on the well-documented 23-28 July convective period during the AMMA 2006 field experiment (Barthe et al., 2010). The large AMMA-SOP dataset at the Niamey AMMA supersite, in particular the ultra-high-frequency (UHF) and Massachusetts Institute of Technology (MIT) Doppler radar and the dense network of rain-gauges, was used to evaluate the fine-scale NWP Applications of Research to Operations at MEsoscale (AROME) model (Seity et al., 2011). Although AROME has been in routine use over western Europe for four years, this was the first time it had been used over a broad West African domain during the monsoon to explore its forecast skills. The main objective of this article is to evaluate the AROME model over West Africa during the WAM season and to assess the impact of some improvements of the initial and coupling atmospheric fields resulting from the assimilation of remotesensing microwave observations (Karbou et al., 2010a, 2010b). The analyses and forecasts were also evaluated against the GPS observations and Tropical Rainfall Measuring Mission (TRMM3B42) rainfall estimates (Huffman et al., 2007). In addition to the scores, a precipitation-features tracking algorithm based on

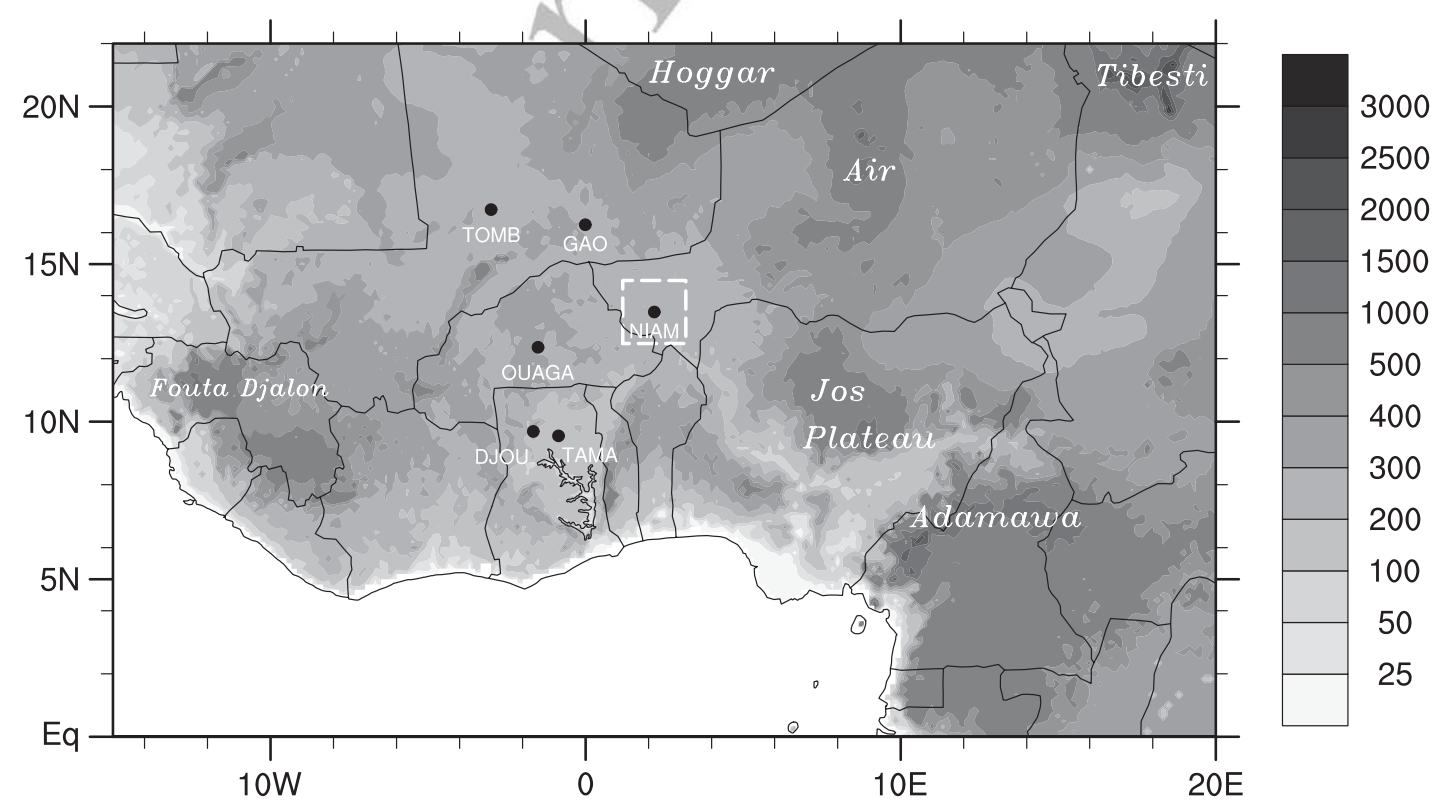

Figure 1. Map of the AROME domain with the geographical labels (relevant orographic features appearing in italics). The grey shaded areas indicate terrain height above mean sea level $(\mathrm{m})$. The dark circles represent the six GPS stations (TOMB for Timbuktu $\left(3^{\circ} \mathrm{W}, 16.73^{\circ} \mathrm{N}\right)$, Gao $\left(0^{\circ}, 16.25^{\circ} \mathrm{N}\right)$, NIAM for Niamey $\left(2.18^{\circ} \mathrm{E}\right.$, $\left.13.48^{\circ} \mathrm{N}\right)$, OUAGA for Ouagadougou $\left(1.51^{\circ} \mathrm{W}, 12.36^{\circ} \mathrm{N}\right)$, DJOU for Djougou $\left(1.66^{\circ} \mathrm{E}, 9.69^{\circ} \mathrm{N}\right)$, TAMA for Tamale $\left(0.86^{\circ} \mathrm{W}, 9.55^{\circ} \mathrm{N}\right)$. The white dotted box represents the boundaries of the domain called 'Niamey box' used in Figure 13. 
$1 \quad 1 \mathrm{~h}$ accumulated precipitation is used over the period of interest 2 to evaluate the forecast skill and the differences of behaviour 3 of individual models. This tracking approach provides objective 4 statistics on the life cycles of the MCSs, such as their diurnal initiation and dissipation and their life span.

Section 2 presents the case-study, the AROME model, the design of the experiments, the data and the evaluation procedure. In section 3, the AROME sensitivity to initial and coupling atmospheric fields from the ARPEGE model is discussed, depending on the ARPEGE configuration and on the assimilation 10 of Advanced Microwave Sounding Unit (AMSU-B) microwave 11 channels. In section 4 , we evaluate the ability of the AROME model to represent the life cycles of MCSs. Conclusions are drawn in section 5 , and we discuss the perspectives provided by such CRM simulations for studying the life cycle of MCSs and their interplay with AEWs.

\section{The case-study and experimental design}

\subsection{Case-study}

To evaluate the AROME simulations, we looked at a sequence of convective events that occurred near Niamey during the period of 25-26 July 2006. It was a period of particularly active convection embedded in a large-scale circulation favourable to convection and characterized by a monsoon surge combined with the passage of an AEW. Barthe et al. (2010) studied the environment of two successive mesoscale convective systems (MCS1 and MCS2 hereafter) using the large AMMA-SOP dataset (UHF radar, MIT Doppler radar, rain-gauges, GPS stations, etc.). The long-lived MCSs were located ahead of, and in phase with, the trough of the AEW, in phase with a strong vertical shear and the intense monsoon surge penetrating up to $18^{\circ} \mathrm{N}$ (Cuesta et al., 2010). From the afternoon of 26 July and for $36 \mathrm{~h}$, convection developed with suppression of organized convection and the occurrence of isolated convective cells. The local convection resulted from some favourable factors (humidity, convective available potential energy (CAPE), weak convective inhibition (CIN)) that triggered convection, while inhibiting factors (midlevel dry layer, weaker low-level wind shear pointing to the north, anticyclonic curvature of the streamlines at $700 \mathrm{hPa}$ ) prevented it from organizing itself and propagating. The MCS1 and MCS2 cases were simulated using the high-resolution Méso$\mathrm{NH}$ model and were extensively analysed using observations acquired during the intensive observation period of AMMA (Barthe et al., 2010). These two situations are therefore of great interest for evaluating the performance of the AROME model. It should be noted that Bain et al. (2011) made a detailed analysis of the structure of this AEW during the 25-29 July period.

\subsection{Configuration of models, design of simulations and method}

\subsubsection{The global ARPEGE forécasting system}

In order to explore the sensitivity of the AROME model to initial and forcing atmospheric fields provided by the French global Action des Recherche Petite Échelle et Grande Échelle (ARPEGE) forecasting system (Courtier et al., 1994), we first briefly describe its characteristics for the two versions Cycle 32 and 33 (CY32 and 33 hereafter) used in the present article. The CY32 ( a T358 (T538) spectral truncation on a stretched sph $\overline{\overline{\bar{\tau}}}$ rith a stretching factor of 2.4, and 46 (60) vertical levels from 17 to $45 \mathrm{~km}$. This configuration leads to a horizontal resolution of about $50 \mathrm{~km}$ $(25 \mathrm{~km})$ over West Africa. The deep convection parametrization is based on the convergence of humidity (Bougeault, 1985; Ducroca and Bougeault, 1995). The major changes in parametrizations brought by the CY33 relative to the CY32 were the introduction of the turbulent kinetic energy (TKE) and a new scheme of shallow convection based on a mass flux closure (Bechtold et al., 2001). The assimilation component of ARPEGE uses a 4D-Var scheme with a $6 \mathrm{~h}$ time window and frequency (Veersé and Thépaut, 1 1998; Rabier et al., 2000).

During the AMMA-SOP, considerable effort has been devoted to update and reinforce the radiosonde network over West Africa (Parker et al., 2008), and increase its frequency with for example four soundings per day at Niamey, Tamale and Parakou (20 miles away from Djougou). Bock et al. (2007) have evidenced an overall dry bias in radiosondes of about $3 \mathrm{~kg} \mathrm{~m}^{-2}$ as compared to GPS. Agusti-Panadera et al. (2010) developed a model-based method to correct the above biases depending on the sonde type and the altitude. They concluded that the assimilation of the whole set of AMMA radiosondes had a positive impact if corrected on the European Centre for Medium-range Weather Forecasts (ECMWF) forecasts, results confirmed by Faccani et al. (2009) for the ARPEGE system. The ECMWF correction method has been implemented in ARPEGE from CY33. In the present article, we assimilated all AMMA radiosondes; nevertheless they are not corrected for CY32 experiments.

To improve the analysis, we also assimilated remote-sensing microwave data from AMSU-B, by using the method developed by Karbou et al. (2010a, 2010b). This sensor provides observations sensitive to the air moisture from the surface to about $20 \mathrm{~km}$ height. The assimilation of channels 2 and 5 over land significantly improved the analysis of the air humidity and temperature at low levels up to $4 \mathrm{~km}$ including over West Africa (Karbou et al., 2010b).

To assess the impact of the above observations on the analysis, we performed a set of four assimilation experiments summarized in Table 1, exploring the sensitivity to the cycle (CY32 and CY33 names) and to the assimilation (or not) from AMSU-B channels over continental surfaces with the suffix $+\mathrm{A}$ (or not). These experiments were performed over a $\sim 2$-month AMMA period (14 July to 11 September 2006), four times per day (0000-0600-1200-1800 UTC).

From this set of four assimilation experiments, we initialized a set of four ARPEGE forecasts (ARP_ series) summarized in Table 2. The ARPEGE forecasts were run over $6 \mathrm{~h}$ for the full $\sim 2$ month period to assess the analysis of precipitation. Nevertheless, for the 23-28 July case-study we performed a set of ARPEGE forecasts over 6 days starting from 23 July at 0000 UTC, to be compared with AROME forecasts.

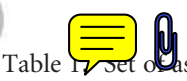

assimilation experiments with the ARPEGE 4D-Var assimilation system.

\begin{tabular}{|c|c|c|c|c|}
\hline Analysis & $\begin{array}{l}\text { ARPEGE } \\
\text { version }\end{array}$ & $\begin{array}{l}\text { Truncation } \\
\text { (resolution } \\
\text { over Africa) }\end{array}$ & $\begin{array}{l}\text { AMSU-B } \\
\text { assimilation }\end{array}$ & $\begin{array}{l}\text { Period of study } \\
\text { for all analyses }\end{array}$ \\
\hline CY32 & Cycle 32 & T358 ( 50 km) & None & $\begin{array}{l}14 \text { July to } 14 \\
\text { September }\end{array}$ \\
\hline $\mathrm{CY} 32+\mathrm{A}$ & Cycle 32 & $\mathrm{~T} 358(\sim 50 \mathrm{~km})$ & $\begin{array}{l}\text { Channels } 2 \text { and } 5 \\
\text { over continent }\end{array}$ & \\
\hline CY33 & Cycle 33 & T598 ( 25 km) & None & \\
\hline $\mathrm{CY} 33+\mathrm{A}$ & Cycle 33 & T598 $(\sim 25 \mathrm{~km})$ & $\begin{array}{l}\text { Channels } 2 \text { and } 5 \\
\text { over continent }\end{array}$ & \\
\hline
\end{tabular}

Table 2 . Set of forecast experiments with the ARPEGE model.

\begin{tabular}{lclll}
\hline Simulation & Model & $\begin{array}{l}\text { Initial state } \\
\text { (analysis) }\end{array}$ & Forced by & $\begin{array}{l}\text { Range forecast and } \\
\text { (period of study) } \\
\text { for all simulations }\end{array}$ \\
\hline ARP_CY32 & ARPEGE & CY32 & None & $\begin{array}{l}\text { 6 h (14 July to } \\
14 \text { September) }\end{array}$ \\
ARP_CY32+A & - & CY32+A & None & \\
ARP_CY33 & - & CY33 & None & \\
ARP_CY33+A & - & CY33+A & None & \\
& & & & $\begin{array}{l}144 \text { h (23-28 } \\
\text { July) }\end{array}$ \\
\hline
\end{tabular}




\begin{tabular}{lclll}
\hline Simulation & Model & Initial state & $\begin{array}{l}\text { Forced by } \\
\text { Range forecast and } \\
\text { (period of study) }\end{array}$ \\
\hline ARO_cplCY32 & AROME & CY32 & CY32 & AROME forced by ARPEGE analysis (hindcast) \\
ARO_cplCY32+A & - & CY32+A & CY32+A & \\
ARO_cplCY33 & - & CY33 & CY33 & \\
ARO_cplCY33+A & - & CY33+A & CY33+A & \\
& & & ARP_CY32 & AROME forced by ARPEGE forecast \\
ARO_cplARP_CY32 & AROME & CY32 & ARP_CY32+A & \\
ARO_cplARP_CY32+A & - & CY32+A & ARP_CY33 & \\
ARO_cplARP_CY33 & - & CY33 & ARP_CY33+A & \\
ARO_cplARP_CY33+A & - & CY33+A & & \\
\hline
\end{tabular}

\subsubsection{The AROME model}

simulations studied in this article were performed using the French high-resolution NWP regional model AROME (Seity et al., 2011). AROME has been operational over France, with a $2.5 \mathrm{~km}$ horizontal resolution, since the end of 2008. AROME is a non-hydrostatic regional model and takes advantage of both the ARPEGE system (dynamical adiabatic core, data assimilation, software) (Courtier et al., 1994; Bubnová et al., 1995) and the Méso-NH research system (Lafore et al., 1998) for most of 24 its physical parametrizations (microphysics, turbulence, shallow 25 convection, surface). AROME is a bi-Fourier spectral limited-area 26 model and uses a two-time-level, semi-implicit, semi-Lagrangian 27 discretization scheme on an A-grid. It reaches high numerical 28 efficiency with time steps greater than $60 \mathrm{~s}$ at $2.5 \mathrm{~km}$ resolution, 29 which is suitable for operational purposes.

The vertical grid contains 60 levels stretched from $10 \mathrm{~m}$ to $20 \mathrm{~km}$ with 28 levels below $3000 \mathrm{~m}$. Physical parametrizations 31 include the Rapid Radiative Transfer Model (RRTM) long-wave 32 (Mlawer et al., 1997) and Fouquart and Bonnel (1980) short33 wave radiation schemes, mixed-phase microphysics (Pinty and 34 Jabouille, 1998), the TKE scheme of Cuxart et al. (2000) and the 35 Interactions Soil-Biosphere-Atmosphere (ISBA) surface scheme 36 (Noilhan and Mahfouf, 1996). The $2.5 \mathrm{~km}$ horizontal resolution 37 has been chosen over France in order to partly bypass the so38 called 'convective grey zone' and to better represent among others 39 the orography, the physiographic data and the type of soil. At 39 this resolution, the deep convection is assumed to be explicitly 40 resolved by the model but the shallow convection requires a 41 specific parametrization of subgrid-scale processes for which the 42 Pergaud et al. (2009) scheme is used. It is a mass flux scheme 43 that parametrizes dry thermals and shallow cumuli. Since 2008, 44 AROME represents a real benefit for French forecasters to handle scores adapted to small scales. Nevertheless, AROME skill has never been assessed over continental tropical regions such as West Africa.

The AROME simulations were initialized at 0000 UTC on 23 July and were run over 6 days to simulate all scales and processes that might impact our convective systems of interest, from the monsoon surge to convection. The simulation domain (Figure 1) covered a large part of West Africa and the Gulf of Guinea $\left(0-22^{\circ} \mathrm{N}, 15^{\circ} \mathrm{W}-20^{\circ} \mathrm{E}\right)$ at $5 \mathrm{~km}$ resolution, representing $696 \times 444$ grid points. The choice of the resolution was a compromise between the need for a resolution high enough to explicitly represent deep convection (without a deep convection scheme) and the use of a domain large enough to simulate both the initiation and propagation of MCSs, and synoptic features such as AEWs interacting with convection. As shown by Weisman et al. (1997) for midlatitudes and by Barthe et al. (2010) over West Africa, although it may be too crude to properly simulate convective cells in research mode (Bryan et al., 2003), this resolution enables salient mesoscale aspects of convection to be captured, obviating the need to use a convection scheme. Some sensitivity experiments performed over West Africa at

$2.5 \mathrm{~km}$ resolution show a better representation of the smaller convective features but they have indicated only a weak impact (not shown) on the representation of the life cycle of the largest MCSs.

\subsubsection{Initialization and forcing of $A R O M E$ simulations}

Over West Africa, we used the AROME model without its own assimilation system, since data were too sparse over the region. Atmospheric and surface initial fields were taken from the 4D-Var assimilation system of the global ARPEGE model, whereas the lateral boundary conditions were provided either by the ARPEGE forecast or by its analysis every $6 \mathrm{~h}$. The one-way coupling was performed at an hourly step so that ARPEGE forecasts were used at intermediate ranges.

We initialized a first set of four AROME simulations forced by the set of four ARPEGE analyses (ARO_cpl series) and a second set of four AROME simulations forced by the set of four ARPEGE forecasts (ARO_cplARP series). Table 3 summarizes our simulations

\subsubsection{Evaluation procedure}

Evaluation against independent GPS observations of TCWV During the SOP of AMMA 2006, six GPS ground stations were deployed over West Africa (Figure 1) at Timbuktu, Gao, Niamey, Ouagadougou, Djougou and Tamale providing hourly measurements of the TCWV (Bock et al., 2007). These observations were not assimilated in NWP models and could therefore be used for an independent assessment of our simulations. Basic statistics (correlations, variance and bias) were computed and presented as Taylor diagrams (Taylor, 2001).

Quantitative precipitation forecasts ARPEGE and AROME simulation skills were quantitatively evaluated in terms of quantitative precipitation forecasts (QPFs). However, an evaluation of this kind is not straightforward because of the natural large spatial and temporal variability of precipitation, especially for convective regimes over West Africa, and also because of the sparse density of the rain-gauge network (see Fig. 2 in Ali et al. (2005)). Consequently, we used the TRMM-3B42 rainfall estimates derived from a combination of microwave satellite observations (SSM/I, TMI, AMSR and AMSU), geosynchronous infrared precipitation estimates and monthly-accumulated rain-gauge data (Huffman et al., 2007). This comprehensive dataset was previously evaluated over our domain of interest (Roca et al., 2010; Jobard et al., 2011; Pierre et al., 2011; Pedinotti et al., 2012; Gosset et al., 2013) and provided instantaneous rain rates every $3 \mathrm{~h}$ at a spatial resolution of $0.25^{\circ} \times 0.25^{\circ}$. For quantitative estimates (i.e. scores), the TRMM-3B42 product and AROME/ARPEGE precipitation forecasts from our simulations were aggregated on a $0.5^{\circ} \times 0.5^{\circ}$ grid.

To assess the ARPEGE and AROME simulations, we calculated the Equitable Threat Score (ETS) against the $24 \mathrm{~h}$ cumulative 
1 TRMM-3B42 rainfall estimate. ETS is a diagnostic score often 2 used (Nuret et al., 2005) in the absence of a climatology event since the hits of forecasts expected by chance are removed. In this study, the ETS was calculated by taking 50 random test samples, each comprising $25 \%$ random data, before averaging the 50 ETSs. The scores were calculated for each rainfall pixel (TRMM-3B42 or forecast) with a range of thresholds for rainfall greater than $0.1,1,2,5,10$ and $20 \mathrm{~mm}_{\text {day }}{ }^{-1}$. The lowest threshold $(0.1 \mathrm{~mm}$ day $^{-1}$ ) gave insights into the system's ability to discriminate rainy 9 from non-rainy days, while the highest threshold corresponded 10 to events associated with MCS.

The $24 \mathrm{~h}$ cumulative precipitation was computed over 0600-0600 UTC periods, more in phase with the life cycle of convective events. In order to evaluate the ARPEGE analysis, the $24 \mathrm{~h}$ cumulative precipitation was calculated by cumulating the $6 \mathrm{~h}$ range forecast of precipitation. The period of interest for ARPEGE analysis spanned 19 July to 11 September 2006. For both ARPEGE and AROME $144 \mathrm{~h}$ range forecasts, the $24 \mathrm{~h}$ cumulative precipitation was computed over the period from 0600 UTC 23 July to 0600 UTC 28 July. For all 12 experiments reported in this article (Table 2), ETSs were statistically 95\% $t$-test significant, even for the $20 \mathrm{~mm}$ day $^{-1}$ threshold.

MCS tracking In order to characterize the individual convective events, a tracking algorithm was applied to the surface precipitation, using the $1 \mathrm{~h}$ accumulated precipitation. This technique simply connects, in space and time, the continuous regions where the $1 \mathrm{~h}$ accumulated precipitation exceeds $2 \mathrm{~mm}$. It corresponds to the first step of a recently developed (Fiolleau and Roca, 2013) infrared-based cloud tracking algorithm. The results presented here are only marginally dependent on the value of the threshold used. With this object-oriented approach, we characterized the morphology of the convective systems, at least in terms of their rainfall signature, in a way similar to the tracking methodology traditionally used for cloud analysis which gave access to a large number of parameters (see for instance Fiolleau, 2010). We focused on the trajectory of the centre of the rain object, its duration and local time of genesis.

In order to validate the MCS tracking based on simulated rain, we also applied the tracking algorithm onto data based on satellite rainfall estimates GSMaP. The GSMaP v5 hourly instantaneous dataset (Ushio et al., 2009) is regridded at the $0.25^{\circ}$ resolution to mimic the simulations. Note that these data have been shown to produce reasonable rainfall characteristics over the domain of study using the AMMA campaign ground observations (Roca et al., 2010).

\section{Evaluation of ARPEGE analysis and of its impacts}

The present section focuses on the evaluation of the four ARPEGE analysis experiments over the West African domain of AROME (Figure 1) over the whole $\sim 2$-month period (14 July to 15 , September 2006). In a second step, we assess the impact of ARPEGE fields on AROME simulations for selected case-studies.

\subsection{Evaluation of the ARPEGE experiments}

\subsubsection{TCWV}

Figure 2 shows the Taylor diagram to evaluate the skill of the set of ARPEGE assimilations (labelled 1-4) for the analysis of TCWV as compared with independent GPS observations at six locations during summer 2006. We found that comparison results depended on the location, with the best performance reached at Niamey (correlation $\sim 0.85$ ) and the worst at Djougou $(\sim 0.55)$. This may be related to the quality of observed data, as the Niamey area was one of the major focuses of AMMA observations whereas calibration troubles for humidity were encountered with the Djougou radiosounding (Bock and Nuret, 2009). All other locations exhibited intermediate performance levels (correlations

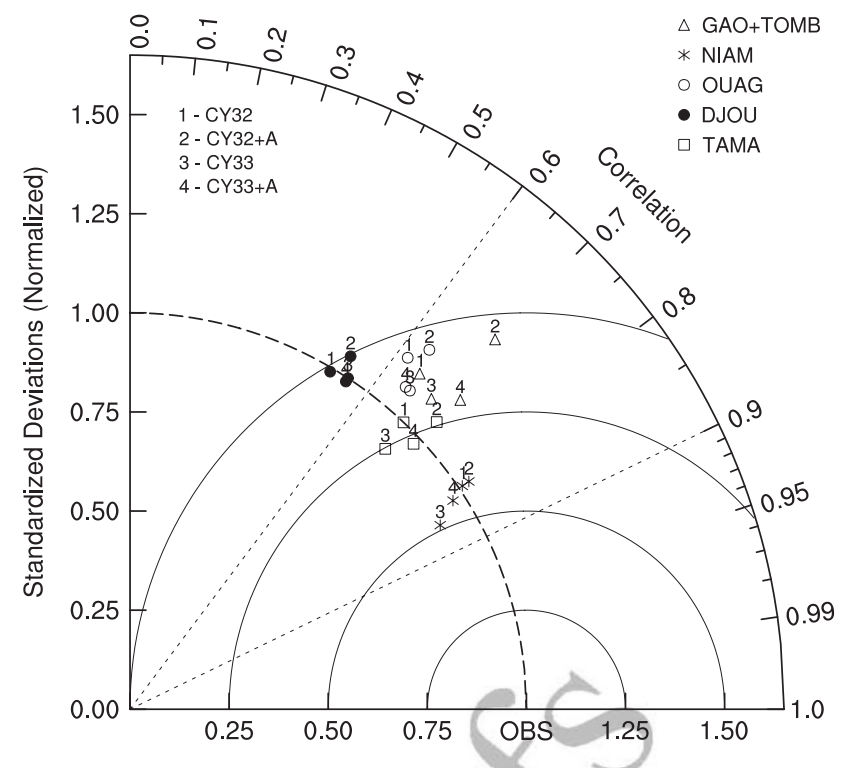

Figure 2. Mean correlation and mean normalized standard deviation of TCWV between the six GPS stations (shown on Figure 1) noted as 'OBS' and the four ARPEGE analyses (CY32, CY32+A, CY33, CY33+A) over the period 19 July to 11 September 2006. Correlations have been carried out with the nearest ARPEGE $1.5^{\circ}$ grid point and for the four main networks (0000, 0600, 1200 and 1800 UTC).

between 0.6 and 0.75 ), with stronger variability at northern Sahel locations (Gao, Timbuktu, Ouagadougou). The change of cycle (32 to 33) was beneficial, with an increase of the correlation and a decrease of the variability. The assimilation of AMSU-B channels $2-5$ also increased the correlation but increased the variability for both cycles. Altogether, the best performance was reached for the experiment CY33+A with the AMSU-B assimilation both for the correlation and the variability, whereas CY32 showed the smallest correlations of all GPS locations over a $\sim 2$-month period.

\subsection{2. $Q P F$}

The ETSs for rain shown in Figure 3 are computed over a $24 \mathrm{~h}$ period by cumulating the ARPEGE $6 \mathrm{~h}$ range simulations initiated by the four ARPEGE assimilation experiments detailed in Table 1. The best scores are reached for weak to moderate rain rates $(1,2$, $\left.5 \mathrm{~mm} \mathrm{day}^{-1}\right)$, whereas heavy rainfall events appear more difficult to capture. ARP_CY33 contributes a positive impact to ETS, especially for heavy rainfalls $\left(10\right.$ and $\left.20 \mathrm{~mm} \mathrm{day}^{-1}\right)$.

Note that ARP_CY33 contained a substantial modification in the physics (boundary layer turbulence, deep and shallow convection parametrization, radiation scheme). These changes in the physics allowed a more realistic representation of the boundary layer including the air moisture, low cloud, night jets

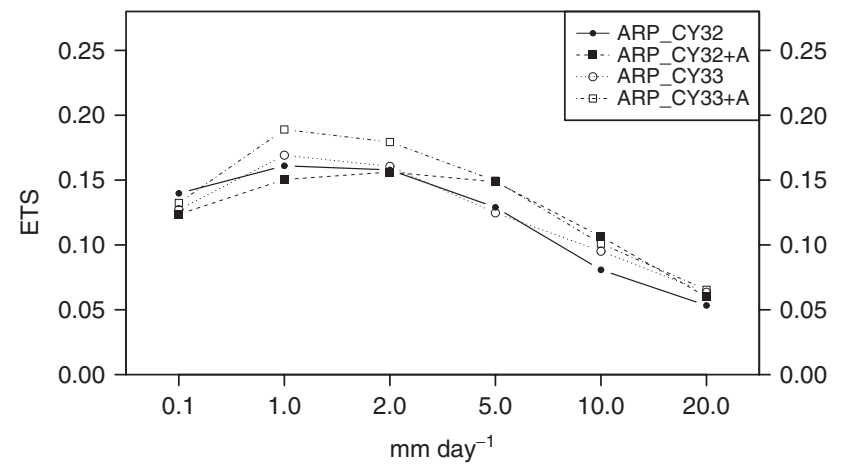

Figure 3. Impact of the assimilation of $\operatorname{AMSUB}(+A)$ on the Equitable Threat Scores (ETS) of $6 \mathrm{~h}$ precipitation forecasts of ARPEGE for cycles CY32 and CY33, as compared with TRMM precipitation on the same $0.5^{\circ}$ grid for six precipitation thresholds cumulated over a $24 \mathrm{~h}$ period (0600-0600 UTC). ETS are computed over the West African domain $\left(0-20^{\circ} \mathrm{N}, 14.8^{\circ} \mathrm{W}-20^{\circ} \mathrm{E}\right)$ of the $\sim 2$-month period (19 July to 11 September 2006). 
and precipitation. The assimilation of AMSU-B channels 2-5 improved the ETS with respect to ARP_CY33 and ARP_CY32 but the improvement was more significant for cycle 33 for all rain rates. A significant benefit appeared when the ARPEGE model used CY33 and assimilated observations sensitive to atmospheric moisture (from AMSU-B). This provided the best analysis $(\mathrm{CY} 33+\mathrm{A})$ in terms of QPF as compared with the satellite precipitate estimate TRMM-3B42.

\subsubsection{Diurnal cycle}

We now examine the ability of the best ARPEGE analysis $(\mathrm{CY} 33+\mathrm{A})$ to describe the diurnal cycle of TCWV as compared with GPS stations in terms of mean bias and correlation (Figure 4(a) and (b)). Except for Niamey, the analysis is moister than the GPS measurements (Figure 4(a)) and Djougou is characterized by the largest bias, in agreement with Bock and Nuret's (2009) findings. As CY33 includes the correction of humidity bias of Agusti-Panadera et al. (2010), a possible explanation of this positive bias might be related to the new physical package of the CY33 and to the assimilation of AMSU-B. Nevertheless an overestimation of the correction is not excluded.

The TCWV bias variability (Figure 4(a)) suggests that the diurnal cycle of TCWV was modified during the analysis, with a large drop at 1200 UTC. Three terms contribute to the evolution of TCWV: advection, precipitation and evaporation. Advection activity is a maximum in the morning due to the nocturnal jet (Couvreux et al., 2010) but cannot explain this drop. This effect is combined with the effect of evaporation, which brings more TCWV into the analysis. Precipitation is probably the best 1 candidate to partly explain this drop, as precipitation is too early 2 and eventually too large, which is typical of the behaviour of 3 large-scale models (see section 4). The fact that the drop is weak for northern Sahel stations (Gao, Timbuktu) for which mean precipitation is the smallest adds weight to this hypothesis.

We also looked at the diurnal variation of correlation between ARPEGE analysis and GPS stations (Figure 4(b)). The comparison shows a significant change of correlation depending on synoptic times (between 0.55 and 0.85 ). Mean correlation values are in agreement with the Taylor diagram of Figure $\beta_{\mathcal{R}}$ with the best correlation for Niamey and the smallest for Djougou. Larger correlations are obtained at 0600 UTC when the variability is expected to be the weakest. The correlation slowly decreases between 0600 and 1200 UTC, which may be due to first triggering of convection, but its dispersion between locations is less probably due to the maximum of data assimilated at this time. The correlation is smaller at 1800 UTC, except for locations in the north of the domain, and is probably associated with the maximum of spatial variability of TCWV generated by the maximum of convection in the afternoon. During the night, the correlation increases and this is probably related to the decrease of convective activity and of surface evaporation.

\subsection{AROME sensitivity to the initial and forcing fields}

Having assessed the performance of the set of assimilations, we now look at their impact on the set of 6-day forecasts performed between 23 and 28 July and summarized in Table $z$.
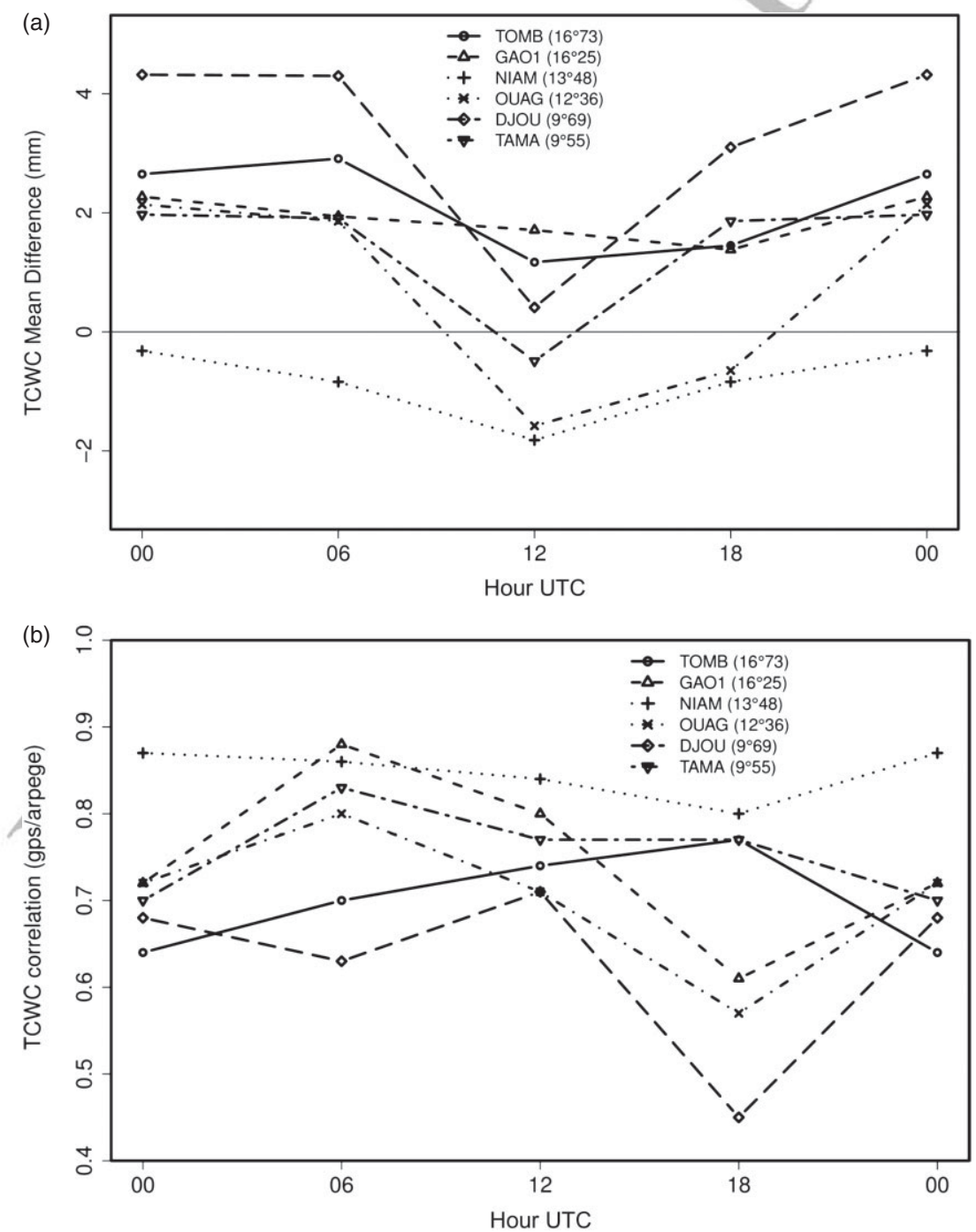


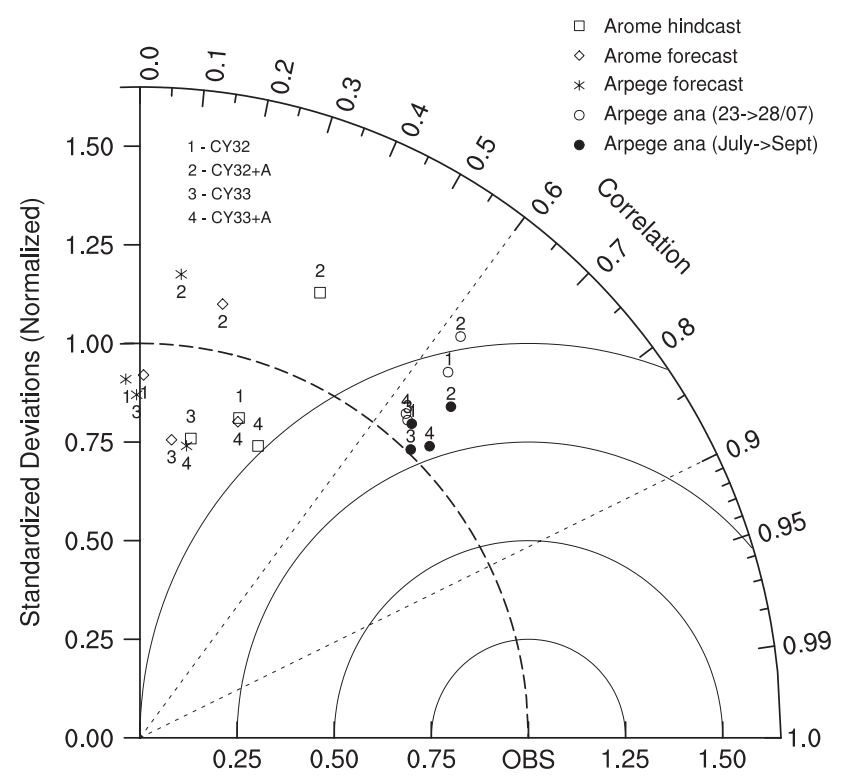

Figure 5. Taylor diagram as in Figure 2 for different sets of analyses and forecasts (labelled 1-4) as compared with the ARPEGE analyses for the six GPS station over the whole 19 July to 11 September 2006 period (black dots) and ove the 23-28 July short period, for the ARPEGE analyses (open circles), for the ARPEGE forecast (black stars), and for AROME forecasts compled with ARPEGE forecast (open diamonds) and coupled with ARPEGE analyses (open-squares) Correlations have been calculated with the mean TCWV value of $\mathrm{A}$ square box of $1.5^{\circ}$ around each GPS location.

\subsubsection{TCWV}

Here we evaluate the TCWV by comparing it with GPS independent observations using a Taylor diagram (Figure 5). First, the mean score of the ARPEGE analysis set (black dots) is consistent with scores noted at the six GPS locations (Figure 2), with a correlation around 0.7 , a weak overestimation of the variability and a positive impact of the assimilation. When a shorter period is used for the present case-study (23-28 July), the results are weakly affected with just a small decrease of the correlation (0.65). The skill for ARPEGE forecasts is very weak or zero (starts on Figure 5) but the AMSU-B assimilation improves it. AROME forecasts drastically improve the skill for the TCWV, and best results are obtained when AROME is coupled with the ARPEGE analysis (open squares) instead of the ARPEGE forecast (open diamonds). Globally, for all experiments on the sensitivity of forecasts to initial and forcing fields, the upgrade from cycle 32 to 33 (labels $1-3$ and 2-4) increases the correlation but decreases the variability of TCWV, whereas the AMSU-B assimilation (labels $1-2$ and 3-4) significantly increases both the correlation and the bias $(+1$ to $+2 \mathrm{~mm}$, figure not shown) and weakly increases the variability of TCWV.

\subsection{2. $Q P F$}

The precipitation ETSs of ARPEGE forecasts in this case are very weak, though positive (Figure 6(a)). Nevertheless, the positive impact of cycle 33 and of the assimilation of AMSU$\mathrm{B}$ is noteworthy. AROME forecasts, whatever the experiment, significantly improve the precipitation ETS (Figure 6(b) and (c)). Their skill is even better than the ARPEGE analysis over the $\sim 2$-month period (Figure 3 ). The best scores are obtained when AROME is coupled with the ARPEGE analysis (Figure 6(c)) instead of with the ARPEGE forecast (Figure 6(b)). The positive impact of cycle 33 and the assimilation of AMSU-B on the ETS is a maximum for AROME experiments coupled with ARPEGE analysis (Figure 6(c)).

Altogether, the best analysis CY33+A allows the best AROME forecasts to be made, in terms of both TCWV and QPF, especially when AROME is coupled with this analysis (experiment
ARO_cplCY33+A). In the following, the latter experiment will be 1 used as a reference.

\section{Analysis of forecasted rain events}

In this section, we study the ability of the CRM to represent the structure and life cycle of the MCSs, and the associated rainfall distribution over the Sahel.

\subsection{Spatial distribution of the daily mean precipitation}

The average rainfall over the period from 23 to 28 July as provided by AROME at $5 \mathrm{~km}$ resolution (Figure 7(a)) has a large spatial variability at small scale, in agreement with surface observations showing strong heterogeneities of rainfall from 2.5 to $20 \mathrm{~mm} \mathrm{day}{ }^{-1}$. This is particularly true over the Sahelian band on variations of $5 \mathrm{~km}$ (Lebel et al., 2000). In order to reduce this natural high spatial variability, well reproduced by AROME, daily precipitation was averaged at $50 \mathrm{~km}$ resolution to allow comparison with the TRMM-3B42 rainfall product (Figure 7(b) and (c)). Overall, there is good agreement between the AROME forecasts and satellite precipitation estimates in terms of northward penetration and intensity of the ITCZ. The mean monsoon penetration as depicted by the intertropical discontinuity (ITD) location (along the $15{ }^{\circ} \mathrm{C}$ dew-point as used by Klüpfel et al. (2011)) delimits the maximum northward penetration of precipitation as depicted by observations on Figure 7(c) (ARPEGE analysis and TRMM). The same feature is simulated by both models. Nevertheless the penetration simulated by AROME is less intense than observed and is shifted westward by about $6^{\circ}$ over north Mali instead over south Algeria (Cuesta et al., 2010). Within the ITCZ, AROME simulates the two observed precipitation maxima, around the reliefs of Cameroon and Fouta Djalon. Nevertheless, the Fouta Djalon maximum is overestimated, particularly at the coast close to Conakry. Also, the relative break of the ITCZ is forecast around the longitude of Greenwich instead of $\sim 8^{\circ} \mathrm{W}$, and the observed suppression of rain over the Ivory Coast is not forecast. In contrast, the ITCZ in ARPEGE (Figure 7(d)) is clearly too broad and weak, and is located too far towards the Equator as compared with the rainfall TRMM product. In particular, the suppression of rain along the Guinea coast is not reproduced. Guichard et al. (2010) have shown that this failure is common to all models at low resolution, when the convection is not explicitly resolved. Contrary to AROME, ARPEGE does not capture the spatial variability of precipitation far from mountainous areas, which is related to propagating MCSs strongly coupled to AEWs. This failure will be analysed in the MCS tracking, section 4.4.

The meridional and zonal distributions of the mean daily precipitation (Figure 8) allow a quantitative comparison of simulations with the TRMM estimates. AROME correctly reproduces the ITCZ location $\left(8-12^{\circ} \mathrm{N}\right)$ and shape but overestimates its rainfall (maximum of 9 instead of $6 \mathrm{~mm} \mathrm{day}^{-1}$ ). ARPEGE performs better for the intensity but the ITCZ location is shifted to the south $\left(\sim 7^{\circ} \mathrm{N}\right)$. The zonal distribution of daily precipitation averaged over the $6-20^{\circ} \mathrm{N}$ band exhibits three regions. East of $6^{\circ} \mathrm{E}$ AROME is in agreement with TRMM precipitation $\left(\sim 4.5 \mathrm{~mm} \mathrm{day}^{-1}\right)$ whereas ARPEGE slightly underestimates it $\left(\sim 3.5 \mathrm{~mm} \mathrm{day}^{-1}\right)$. In the central Niamey region $\left(2^{\circ} \mathrm{W}-6^{\circ} \mathrm{E}\right)$ both AROME and ARPEGE weakly underestimate it $(\sim 3$ instead of $\sim 4.5 \mathrm{~mm} \mathrm{day}^{-1}$ ). Going westward from $6^{\circ} \mathrm{W}$, both simulations clearly diverge from the satellite estimate. The overestimation of rain around Fouta Djalon is greater for AROME.

\subsection{Representation of MCSs, AEW and the monsoon surge}

Similar to the analysis by Barthe et al. (2010), Figure 9 shows the longitude (a) and latitude (b) Hovmüller diagrams of the 3-hourly 3B42 instantaneous precipitation and of the circulation as analysed by ARPEGE. During the 23-28 July period, the

\section{2} 3 
(a)

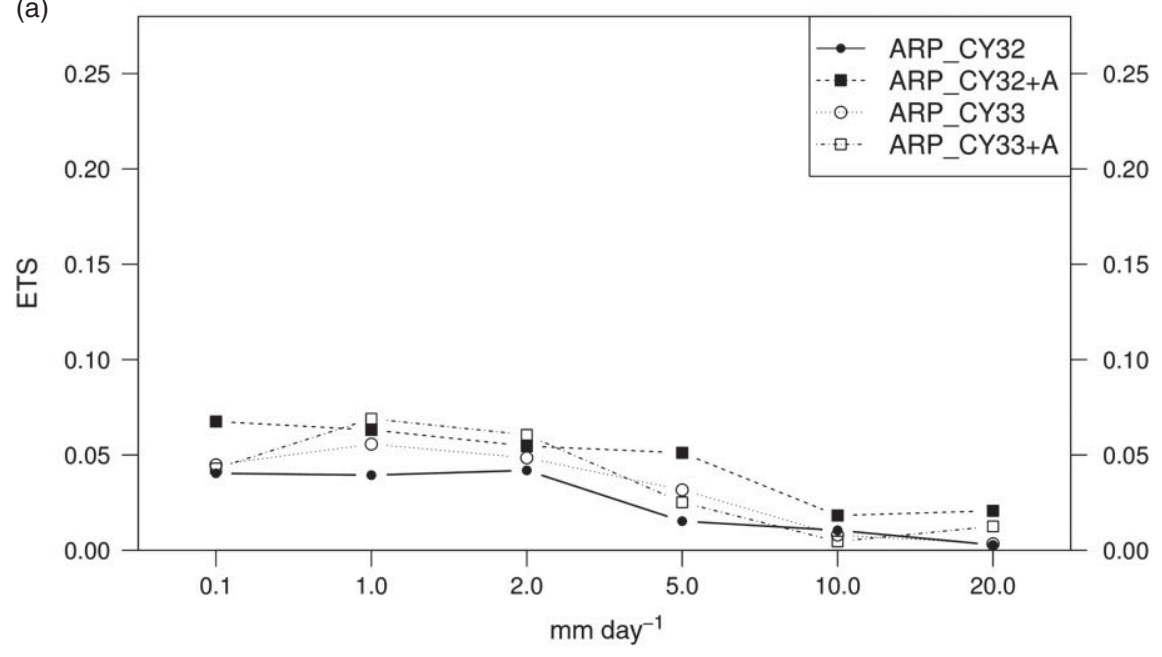

(b)
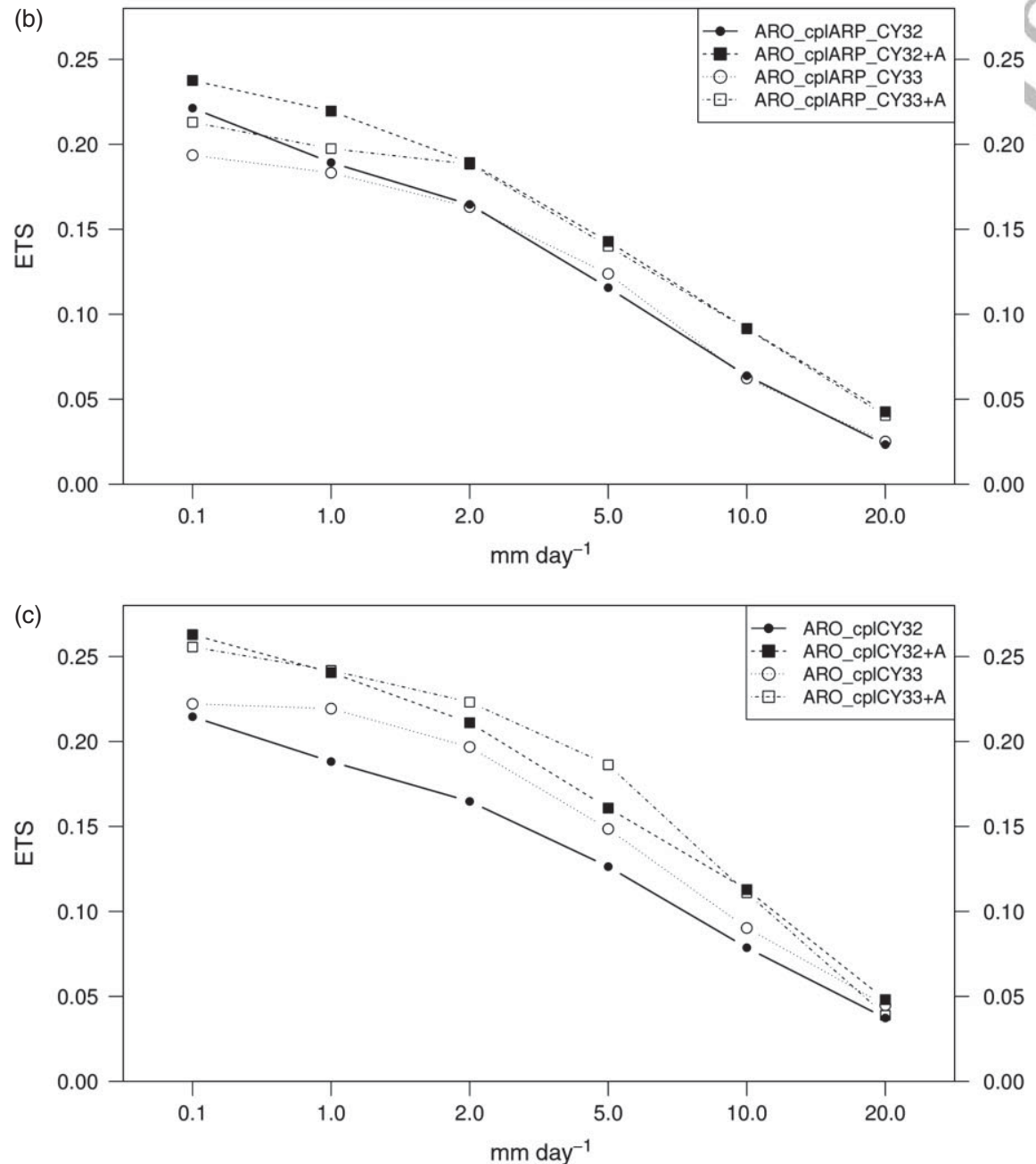

Figure 6. Precipitation ETS as in Figure 2, but for $144 \mathrm{~h}$ range set of forecasts starting on 23 July 2006 at 0000 UTC for: (a) ARPEGE model, (b) AROME coupled 50 with ARPEGE forecast, and (c) AROME coupled with ARPEGE analysis.

convective activity was modulated by two successive major events, an AEW circulation (a) followed by a monsoon surge (b). This period was characterized by high AEW activity (Janicot et al., 2008; Bain et al., 2011) moving at a mean speed of $10 \mathrm{~m} \mathrm{~s}^{-1}$, with an intense oscillation of the meridional wind $\left( \pm 5 \mathrm{~m} \mathrm{~s}^{-1}\right)$ at $700 \mathrm{hPa}$ with a $\sim 3.5$ day period at Niamey (Figure 9(a)). Barthe et al. (2010) have shown that a monsoon surge occurred on 25 and 26 July, corresponding to a northward penetration of the TCWV, preceded by a reinforcement of the heat-low that allowed the southwesterly monsoon flux to intensify at low level (Figure 9(b)). Convection was characterized by westward fastmoving systems, with the passage over Niamey of two major events, MCS1 and MCS2, ahead of and in phase with the trough at 0600 UTC and 2400 UTC, respectively, on 25 July. On 26-27 53 July, in the ridge vicinity, convection was isolated and weak before the passage of a new MCS on the following night. The 55 latitude-time diagram (Figure 9(b)) indicates that Niamey was located just on the northern flank of MCS1 and on the southern flank of MCS2. The trajectory of the last MCS was more to the south.

The AROME forecast scenario (Figure 10) shows many 59 similarities with the observed one summarized above (Figure 9): 60 similar AEW and monsoon surge, associated with westward 61 fast-moving MCSs. We can nevertheless see some differences: 62 simulated MCS1 and MCS2 are both shifted a little to the 63 south $\left(\sim 2^{\circ}\right)$; they pass over Niamey a few hours earlier and 64 
(a)

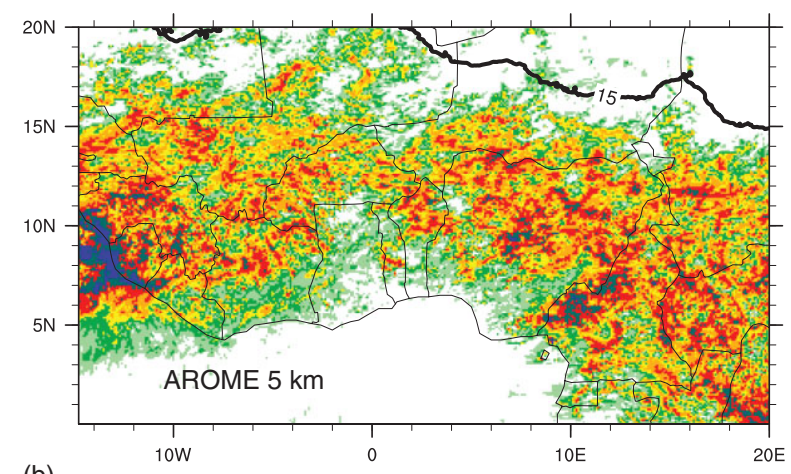

(b)

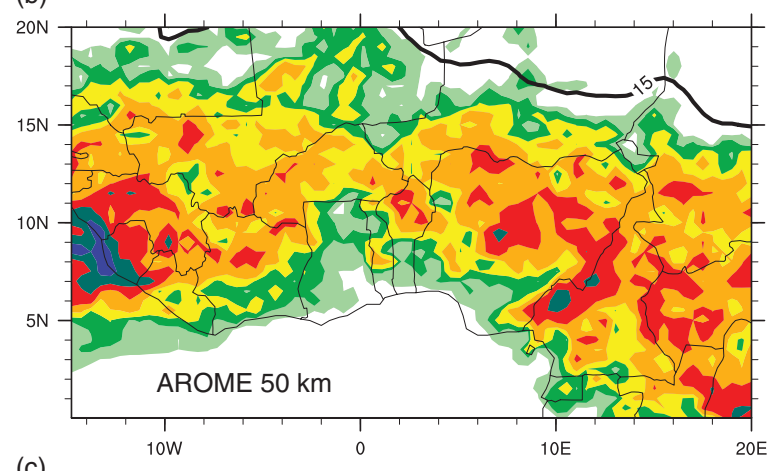

(c)

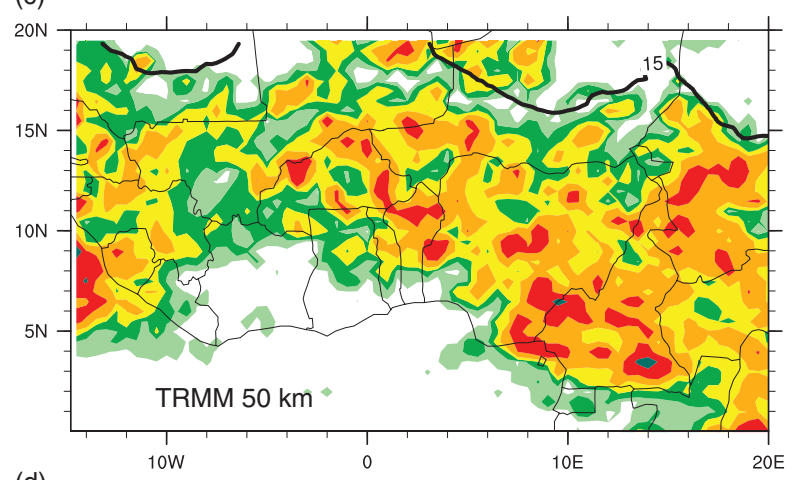

(d)
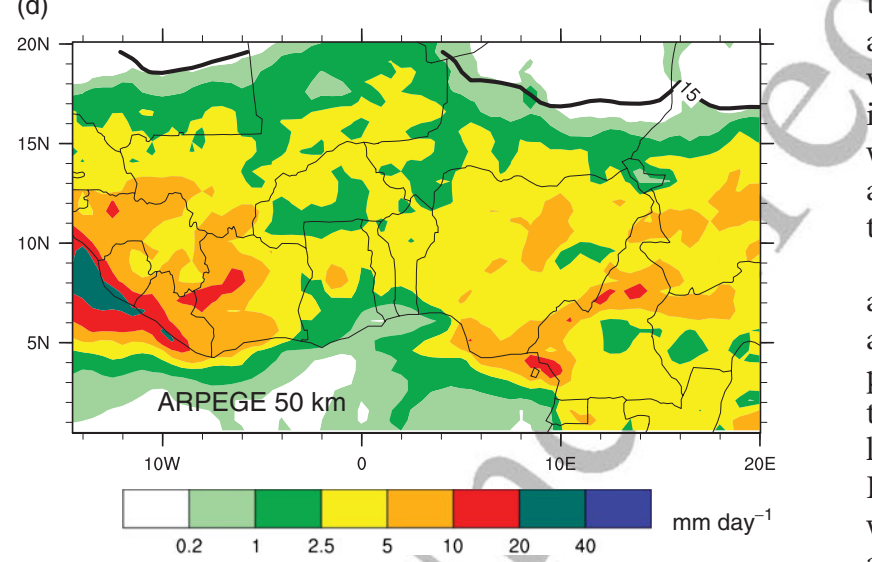

Figure 7. Mean of the $24 \mathrm{~h}(0600-0600 \mathrm{UTC})$ cumulated rain rate $\left(\mathrm{mm} \mathrm{day}^{-1}\right)$ and the surface $15{ }^{\circ} \mathrm{C}$ dew-point (mean extent of the ITD) averaged over the 23-28 July period: for the AROME forecast (a) at $0.05^{\circ}$ resolution and (b) at $0.5^{\circ}$ resolution; (c) for the TRMM-3B 42 product at $0.5^{\circ}$ resolution with ITD calculated from the ARPEGE analysis at $0.5^{\circ}$ resolution; and (d) for the ARPEGE forecast at $0.5^{\circ}$ resolution. the diurnal convection is a little too active, especially on 26 July. West of $4^{\circ} \mathrm{W}$, the intensification of MCSs is too high compared with the TRMM-3B42 estimate, especially on arriving over Fouta Djalon and at the coast. The coupling with ARPEGE, which also presents too much convection in this region, may have contributed to this overestimation. Nevertheless, positive AEW-convection feedback could also explain this increase, since the vorticity anomalies at $700 \mathrm{hPa}$ from AROME are increased by a factor 5 when arriving over Fouta Djalon (not shown).
The same behaviour was noted for the experiment coupled with ARPEGE (ARO_cplARP_CY33+A), while ARPEGE itself did not 2 exhibit such behaviour. Further analysis of AROME simulations will be necessary to quantify and better understand the impact of the positive feedback between MCSs and AEW, and of the Fouta Djalon mountains (Berry and Thorncroft, 2005).

Figure 11 is identical to Figures 9 and 10 except for the ARPEGE forecast. Whereas the mean daily precipitation of ARPEGE was fairly acceptable (Figure 8), its temporal and spatial distributions at finer scale disagree markedly with observations. ARPEGE cannot capture the modulation of precipitation by the AEW passage and by the monsoon surge. Also, there is no trace of the fast-moving MCSs, which are a major characteristic of the convection organization over the Sahel. The signal is dominated by a strong diurnal cycle with a peak of convection at around 1500 UTC, about $3 \mathrm{~h}$ earlier than actually observed. Outside this diurnal cycle, the convective activity depends weakly on the latitude and longitude, is similar from one day to another, and the period of suppressed convection behind the trough is not forecast. So ARPEGE does not represent the strong variability of the convection over the Sahel, unlike AROME, which succeeds thanks to its high resolution. It should be noted that ARPEGE quickly damps the AEW introduced at the initial state. The lack of (or wrong) coupling between convection and AEW may provide an explanation for this behaviour of ARPEGE using a convection parametrization. Sane et al. (2012) detected similar bias concerning the diurnal cycle as compared with rain-gauge data over Senegal for the LMDZ model. This behaviour was improved by a new parametrization set.

According to theoretical considerations (Thorncroft and Hoskins, 1994a, 1994b; Hall et al., 2006), convection is enhanced ahead of or along the AEW trough. Assuming that ARPEGEanalysed winds are reasonably accurate, the present case-study confirms this conceptual model since, at Niamey, the peaks of TRMM-3B42 precipitation are located in the $700 \mathrm{hPa}$ northerly flow (25 July at 0900 UTC) and along the trough (26 July at 0000 UTC) and then decrease until 27 July in the $700 \mathrm{hPa}$ southerly flow (Figure 9(a)). AROME correctly simulates this feature (Figure 10(a)). Thorncroft et al. (2008) showed that the location of long-lived convection is consistent with the adiabatic dynamical forcing implied by the advection of the vorticity perturbation ahead of AEWs. AROME (Figure 12(a)) is in agreement on this point, especially for MCS1, which coincides with a positive potential vorticity anomaly at $320 \mathrm{~K}$ (between 700 and $600 \mathrm{hPa}$ in July over West Africa), located ahead of the AEW trough.

More recently Poan et al. (2012) showed that AEWs could be also tracked by their signature in terms of TCWV and could be associated with a monsoon surge also detected by a northward penetration of TCWV (Couvreux et al., 2010). Figure 12 provides this 'TCWV view' for AROME using time-longitude and latitude-time diagrams of the anomaly of TCWV. As suggested by Poan et al. (2012), this period of high AEW activity is associated with the passage of a TCWV positive anomaly $(>4 \mathrm{~mm})$ moving at the same speed (Figures 12(a) and 10(a)) and with the monsoon surge (Figure 12(b)). At finer scales, AROME shows that rain events are in phase with TCWV local positive anomalies (Figures 10(b) and 12(b) This is the case for MCS1 and MCS2 $(>6 \mathrm{~mm})$ at their pa $\bar{\equiv}$ over Niamey and also for a first event of low intensity on 24July at 0900 UTC, which is in phase writh the first rain peak detected by TRMM-3B42 (Figure 9(b)) strong positive TCWV anomaly in the late afternoon of 26July located north of $12^{\circ} \mathrm{N}$ is not associated with an MCS since the synoptic environment is unfavourable as analysed in detail by Barthe et al. (2010). In particular, the strong southerly winds at $700 \mathrm{hPa}$ behind the trough (Figure 9(a)) are generally associated with the subsiding phase of the AEW. These features exhibited by the AROME forecast are in agreement with the ARPEGE analysis. They confirm that TCWV positive anomalies favour convection but other ingredients, such as the dynamics and related forcing, CAPE, CIN and shear, must also be considered.
1 2 3 4 5 8 9 10 11 12 13 14 15 

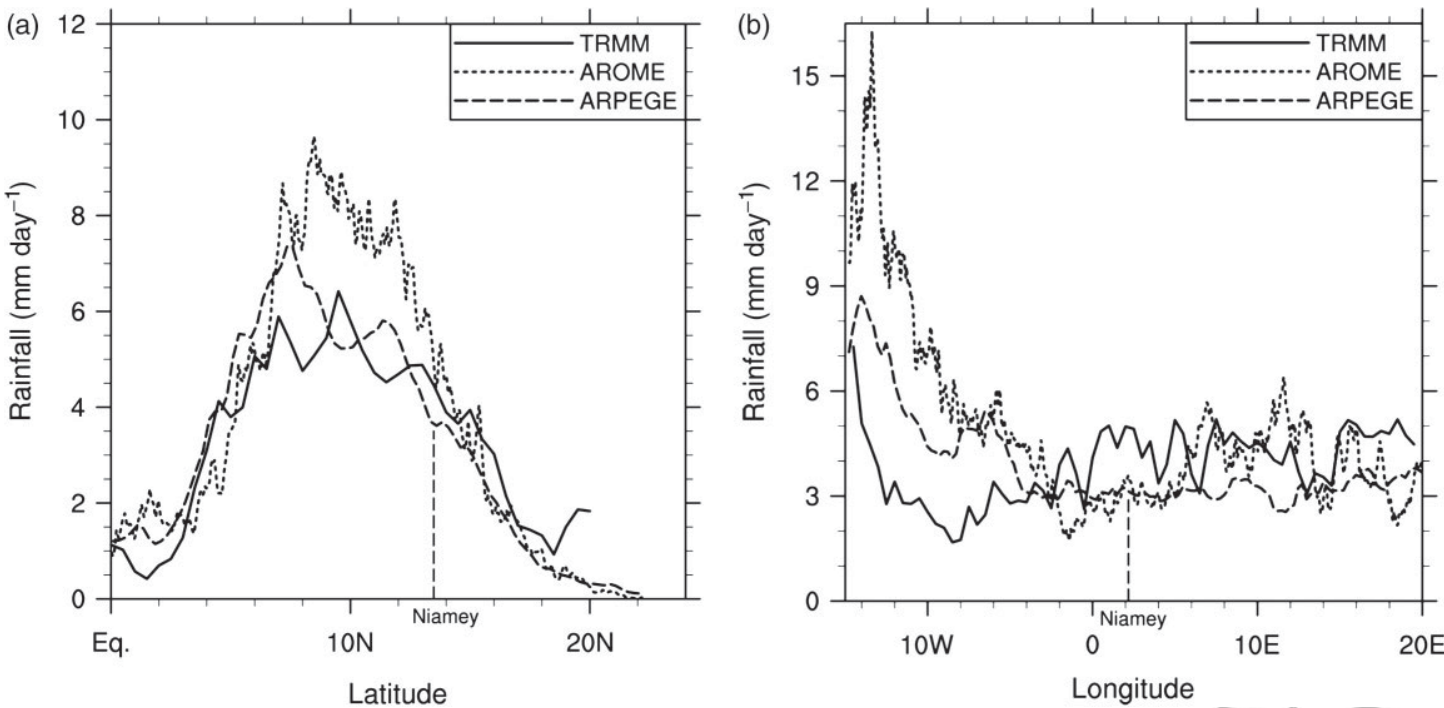

Figure 8. (a) Meridional distribution of the zonal mean daily (0000-0000 UTC) precipitation ( $m m$ day ${ }^{-1}$ ) averaged over the $23-28^{\prime}$ July period and between $15^{\circ} \mathrm{W}$ and $20^{\circ} \mathrm{E}$. (b) Zonal distribution of mean daily precipitation averaged between 6 and $20^{\circ} \mathrm{N}$. The distributions are shown for the TRMM-3B 42 product (solid lines), AROME (dotted lines) and ARPEGE (dashed lines), all at $0.5^{\circ}$ resolution.

(a)

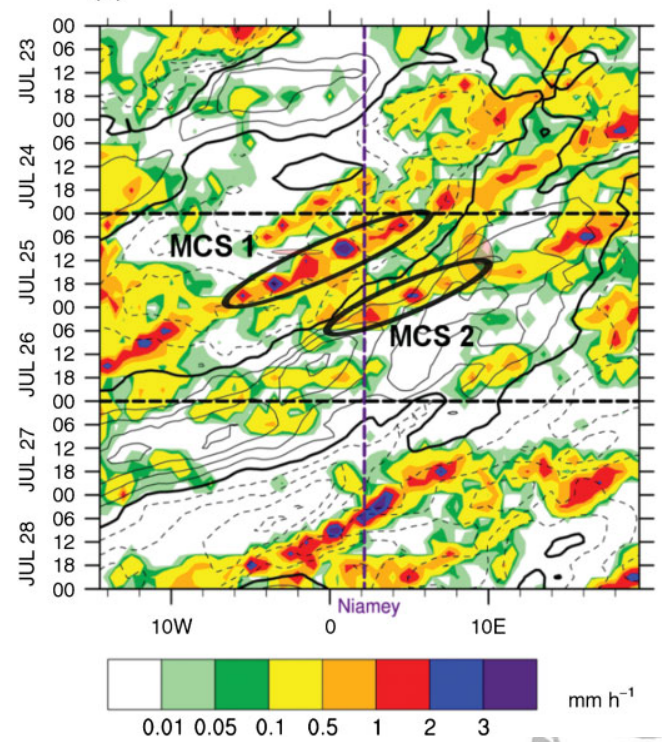

(b)

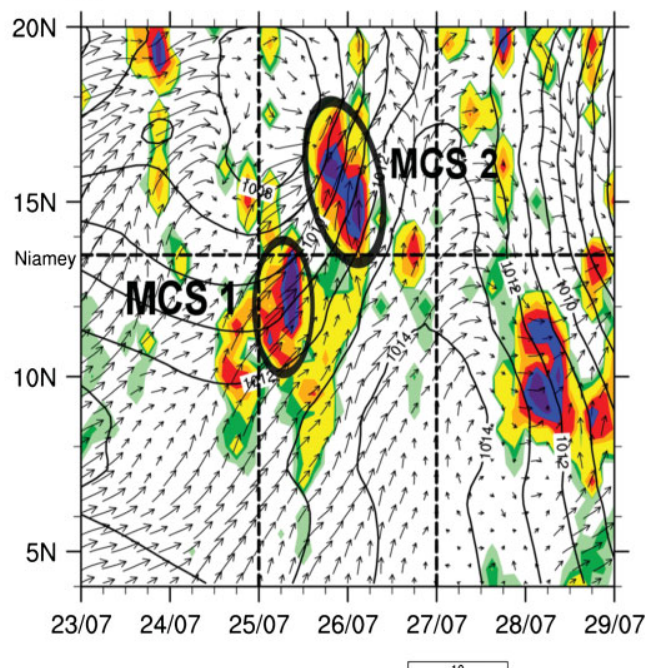

Figure 9. (a) Hovmüller diagram of the TRMM-3B42 $3 \mathrm{~h}$ precipitation $\left(\mathrm{mm} \mathrm{h}^{-1}\right.$, coloured areas) and the meridional wind at $700 \mathrm{hPa}$ (isocontours every $2 \mathrm{~m} \mathrm{~s}^{-1}$ with a thick solid line for 0 ; solid and dashed lines for southerly and hortherly winds respectively) for the $23-28$ July period and averaged between 8 and $15^{\circ} \mathrm{N}$. The horizontal lines mark the period of interest (25-26 July) and the vertical line the longitude of Niamey. (b) Similar Hovmüller diagram to (a) but for the time-latitude of TRMM-3B42 $3 \mathrm{~h}$ precipitation ( $\mathrm{mm} \mathrm{h}^{-1}$, coloured areas), mean-sea-level pressure (MSL in hPa, black lines) and wind at $925 \mathrm{hPa}\left(\mathrm{m} \mathrm{s}^{-1}\right.$, vectors) averaged between 0 and $4^{\circ} \mathrm{E}$. The horizontal dark dashed line represents the latitude of Niamey. For both figures, the black ellipses delineate rain related to MCS1 and MCS2. MSL and winds are from the ARPEGE analysis at a $6 \mathrm{~h}-0.25^{\circ}$ resolution and the ARPEGE forecast at a $3 \mathrm{~h}-0.25^{\circ}$ resolution respectively.

\subsection{Evaluation near the Niamey AMMA supersite}

The AMMA SOP in 2006 provided a unique observation dataset allowing detailed evaluation of simulations in the spirit of the one conducted by Barthe et al. (2010) for the Méso-NH research simulation system. Here, we perform an evaluation for the AROME reference simulation near the Niamey supersite. For this purpose, Figure 13 shows the temporal evolution of the vertical profile of the wind and of some surface parameters over the 23-28 July period, averaged in a $2^{\circ}$ square box as outlined on Figure 1 (white dashed square).

AROME simulates the passage of four precipitation events through the Niamey box (blue bars in Figure 13(b)). The first event occurs on 24 July between 0900 and 1200 UTC. This system appears in TRMM-3B42 (Figure 9(b)) but the intensity of rainfall and the extent of the storm are overestimated by the model. In AROME, MCS1 passes just south of the Niamey box (Figure 10(b)) and, consequently, the event it not detected in the rainfall time series in Figure 13(b) and (c). The passage of
MCS2 is correctly simulated but $6 \mathrm{~h}$ early. Weak precipitation occurs on the evening of 27 July in agreement with TRMM-3B42 accumulated rain (Figure 13(c)). Finally a fourth event occurs on the evening of 28 July and is well captured by AROME. So, because of the high spatial variability of convection, the scenario of precipitation events is not recovered in detail, but the total amount of precipitation accumulated during these six days is seen similarly by TRMM-3B42 estimates and by AROME $(22 \mathrm{~mm})$. Barthe et al. (2010) have provided independent estimations of accumulated rain during the two days (25-26 July) in the $1^{\circ} \times 1^{\circ}$ square around Niamey computed from the AMMA-Coupling the Tropical Atmosphere and the Hydrological Cycle (AMMACATCH) network of 54 rain-gauges (Cappelaere et al., 2009) and from the MIT radar. They converge on a $14-15 \mathrm{~mm}$ value very similar to the TRMM estimate (Figure 13(c)) for the same period but on a larger, $2^{\circ} \times 2^{\circ}$, square.

The red curve on Figure 13(b) corresponds to the spatial variance of the surface wind in the Niamey box. As used by Kocha et al. (2013), it is a good indicator of the occurrence of gust fronts 
(a)
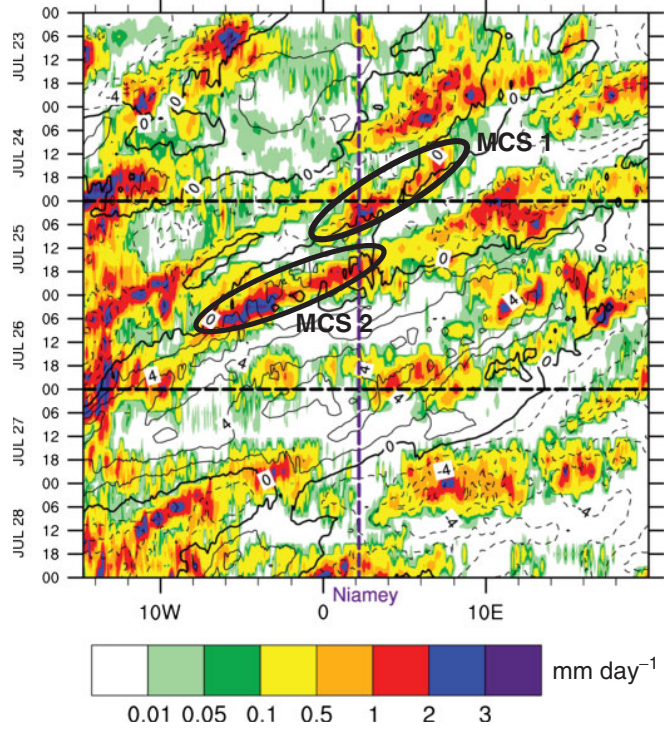

(a)

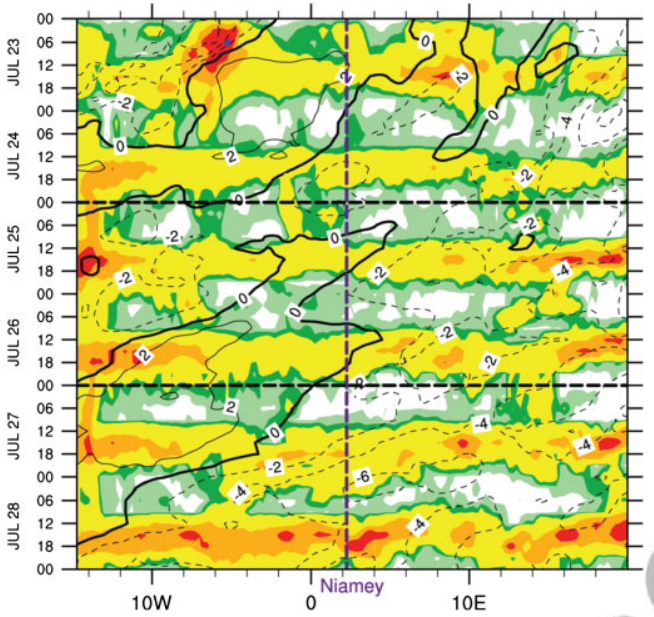

(b)

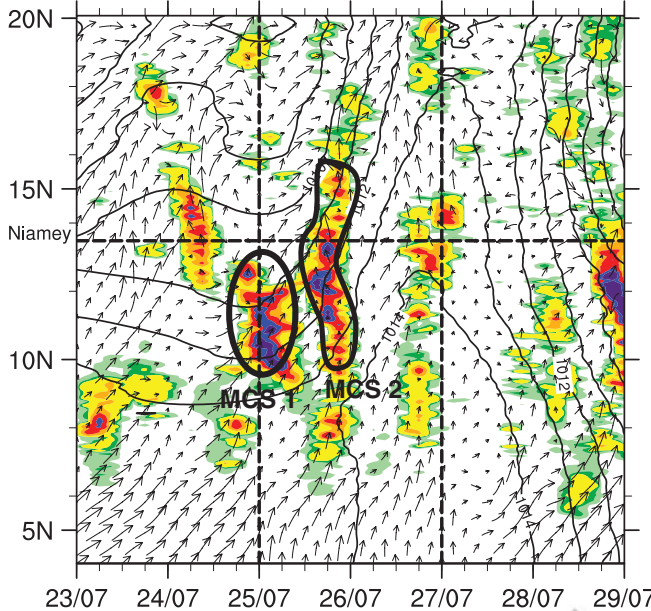

$\begin{array}{lllllll}23 / 07 & 24 / 07 & 25 / 07 & 26 / 07 & 27 / 07 & 28 / 07 & 29 / 07\end{array}$

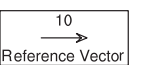

1

2

5

6

7

8

10

11

12

13

14

(b)

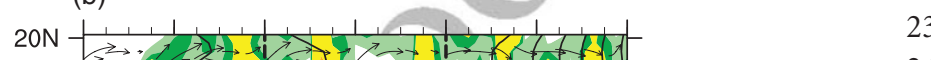

24

25

26

27

$15 \mathrm{~N}-1 \mathrm{~N}-1 \mathrm{Z}-28$

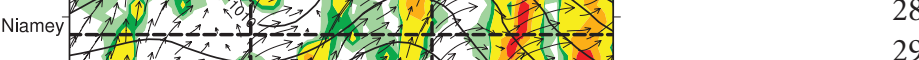

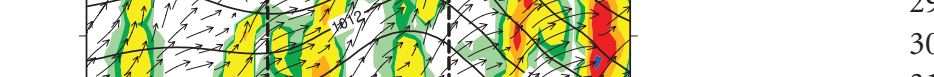

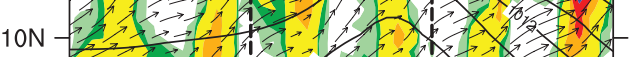

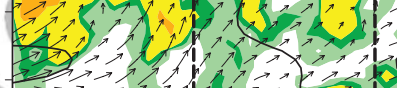

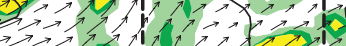

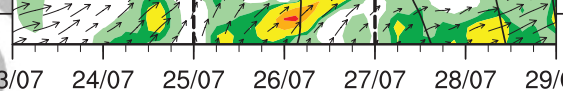

$\begin{array}{lllllll}23 / 07 & 24 / 07 & 25 / 07 & 26 / 07 & 27 / 07 & 28 / 07 & 29 / 07\end{array}$

$\underset{\text { Reference Vector }}{\stackrel{10}{\longrightarrow}}$

30

31

33

34

35

36

37

38

39

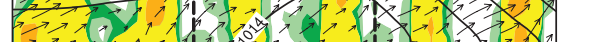

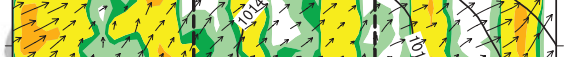

Figure 11. As in Figure 9, but for the ARPEGE $144 \mathrm{~h}$ forecast (a)

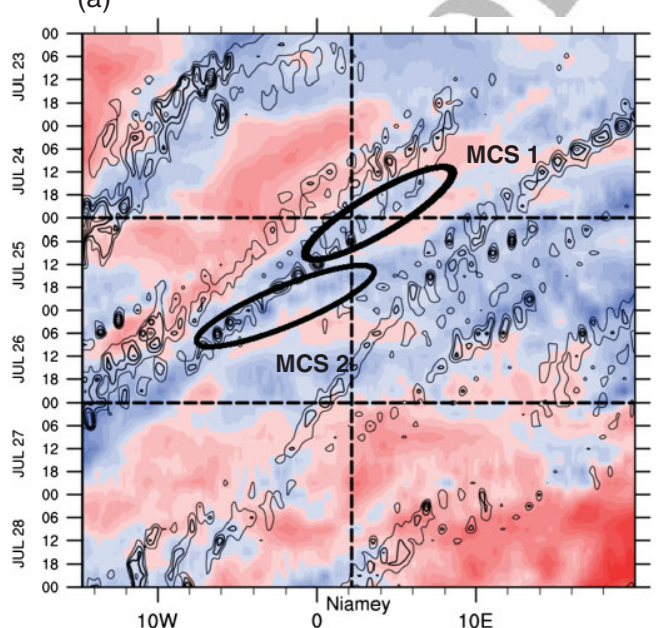

(b)

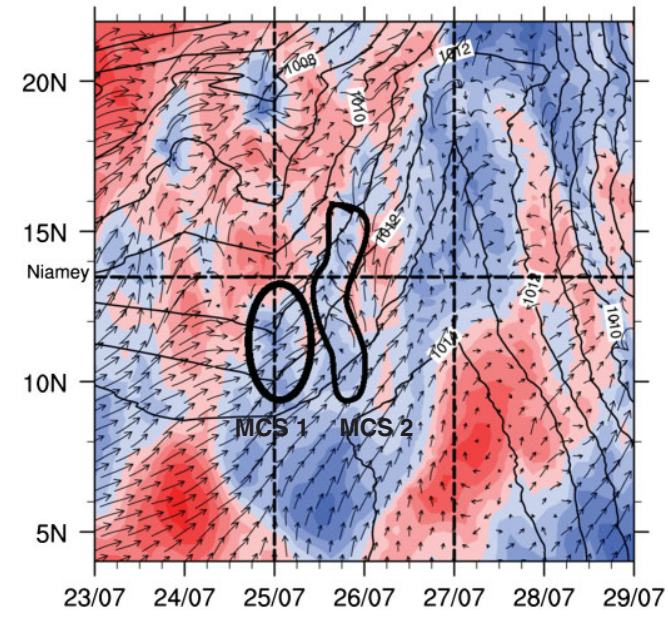

40

41

42

43

44

45

46

Figure 12. (a) Hovmüller diagram of the TCWV anomalies (coloured areas in $\mathrm{mm}$ ) and the potential vorticity anomalies (isocontours from 0.1 to $0.8 \mathrm{PV}$ unit with 0.1 interval) at the $320 \mathrm{~K}$ surface (located between 600 and $700 \mathrm{hPa}$ in July) for the AROME $144 \mathrm{~h}$ forecast. The mean TCWV used to compute anomalies are calculated over the 23-29 July period for each point of longitude. (b) As in Figure 9(b) but for TCWV anomalies instead of precipitation calculated for each latitude for the AROME $144 \mathrm{~h}$ forecast. 


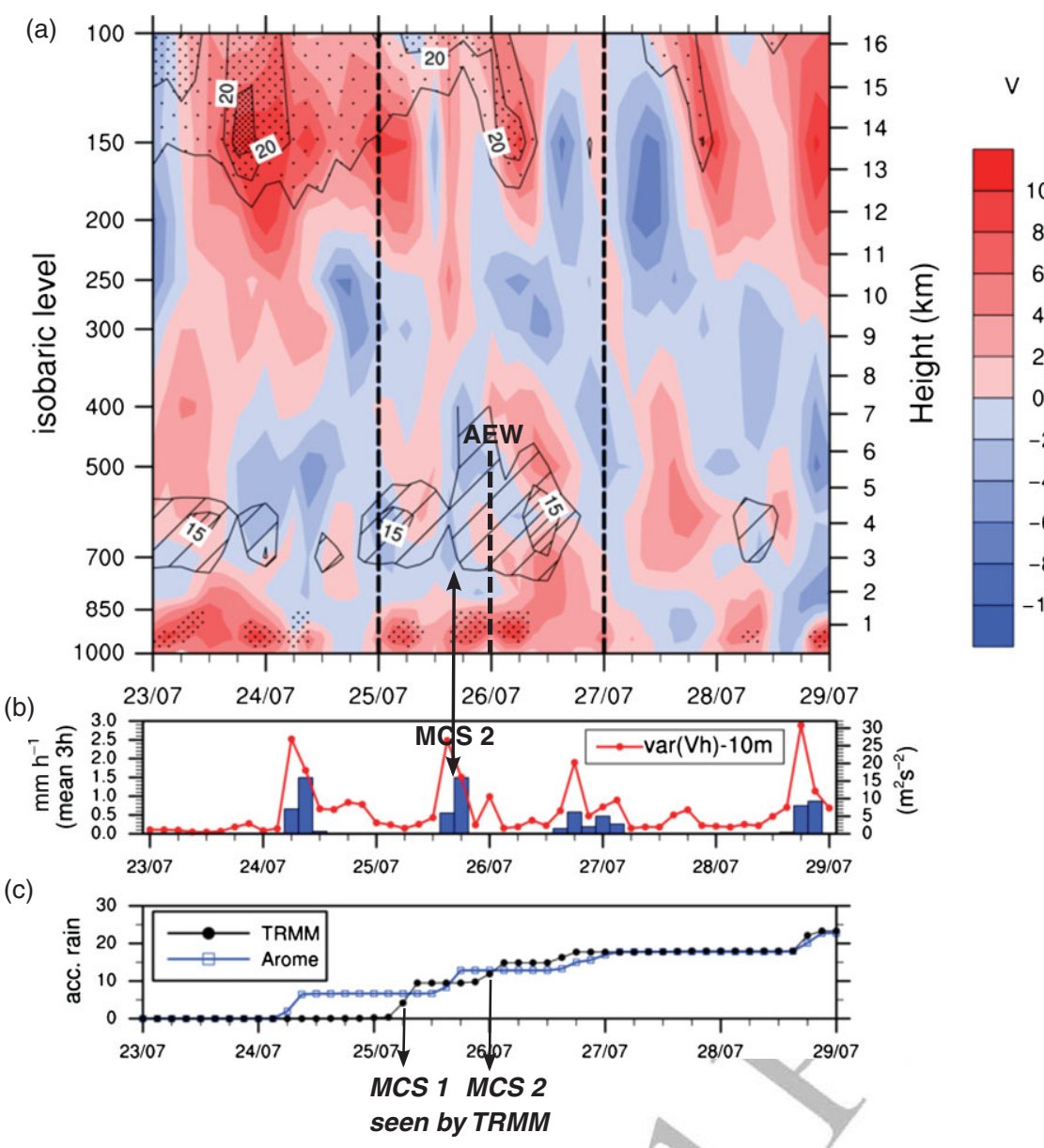

Figure 13. Temporal evolution over the $13-28$ July period from the AROME model averaged in the Niamey box $\left(12.5-14.5^{\circ} \mathrm{N}, 1.2-3.2^{\circ} \mathrm{E}\right)$ (dashed square on Figure 1) of different parameters. (a) The meridional wind $v\left(\mathrm{~m} \mathrm{~s}^{-1}\right.$; red and blue colours for southerly and northerly winds respectively). At low levels, periods of intense monsoon flux have been outlined with dotted areas for horizontal wind speed greater than $7.5 \mathrm{~m} \mathrm{~s}^{-1}$, at midlevels coarse and fine hatched areas for wind speeds greater than 12.5 and $15 \mathrm{~m} \mathrm{~s}^{-1}$ outline a strong African Easterly Jet, and at upper levels coarse, regular and fine dotted areas for wind speeds greater than 17.5, 20 and $22.5 \mathrm{~m} \mathrm{~s}^{-1}$ outline a strong Tropical Easterly Jet. The thick dashed line indicates the African Easterly Wave trough as detected by the UHF radar (Fig. 6 of Barthe et al. (2010)). (b) The $3 \mathrm{~h}$ precipitation $\left(\mathrm{mm} \mathrm{h}^{-1}\right.$ ) (blue histogram) and the surface wind spatial variance simulated by AROME at the Niamey box scale $\left(\mathrm{m}^{2} \mathrm{~s}^{-2} ;\right.$ red curve). (c) The cumulated rain ( $\mathrm{mm}$ ) simulated by AROME (blue squared curve) and TRMM (3B42) estimate (dark dotted curve).

associated with convective cold pools. So, the passage of each simulated event at Niamey is associated with a peak of variance $\left(25-30 \mathrm{~m}^{2} \mathrm{~s}^{-2}\right)$ and a decrease over several hours, corresponding to the passage of the convective and stratiform parts, respectively, of the MCS as displayed by the MIT radar.

The evolution of the profile of meridional wind (Figure 13(a)) can be directly compared with the observations of the UHF profiler and the MIT radar at Niamey up to $6 \mathrm{~km}$, as displayed by Barthe et al. (2010) (their Figs 6 and 7). AROME (Figure 13(a)) reproduces the observed evolution of the meridional wind profile quite well (their Figs 6(b) and 7(b)). At low level, the variability of monsoon flow intensity and depth fits the observations, with the superposition of several scales. First, a clear diurnal cycle is noted, maximum (dotted areas for winds $\geq 7.5 \mathrm{~m} \mathrm{~s}^{-1}$ at $925 \mathrm{hPa}$ ) just before sunset in connection with the nocturnal jet, in agreement with previous studies (Parker et al., 2005; Peyrillé and Lafore, 2007; Lothon et al., 2008). Second, synoptic features such as the monsoon surge and the trough passage correspond to a reinforcing of the monsoon on 25 and 26 July, erasing its diurnal cycle. The previous heat-low reinforcement on 24 July, noted on Figure 12(b), may explain the monsoon intensification as suggested by Couvreux et al. (2010) and Poan et al. (2012). Nevertheless, at a smaller scale, the idea that convection itself contributes to this acceleration cannot be excluded, in agreement with LeMone et al. (1998), who show hat the monsoon acceleration is maximum just ahead of MCSs and that it can occur as far as $500 \mathrm{~km}$ from the convective As previously discussed with the time-longitude diagram (Figure 9(a)), the reversal of northerly to southerly winds at
$700 \mathrm{hPa}$, corresponding to the trough passage, observed at Niamey on 26July 0000 UTC is in good agreement with the UHF profiler (vertical dashed line on Figure 13(a)) (see Fig. 6b of Barthe et al. (2010)). The midlevel penetration of southerly wind (up to $\sim 7 \mathrm{~km}$ ) simulated by AROME behind the AEW trough resembles the observed one, but its duration and intensity are a little less. The modulation of the African easterly jet (AEJ) intensity around $600 \mathrm{hPa}$ (hatched areas on Figure 13(a)) suggests that the AEJ weakens during the passage of MCSs $\left(\sim 12.5 \mathrm{~m} \mathrm{~s}^{-1}\right)$, but is reinforced ahead and behind (up to $17 \mathrm{~m} \mathrm{~s}^{-1}$ ) in relation with the Rear Inflow Jet (Smull and Houze, 1987; Lafore and Moncrieff, 1989; Diongue et al., 2002). At the upper level, the circulation cannot be compared with observations but agrees with the ARPEGE analysis (not shown), with a strong northeasterly Tropical E y Jet (TEJ) a few days before and ahead of the MCS1 and $\overline{\bar{\sigma}} 2$ and a weakening behind. The passage of these MCSs on 25July corresponds to an intense divergent anticyclonic flow resulting in an intensification of the TEJ $\left(30 \mathrm{~m} \mathrm{~s}^{-1}\right)$ in the southwestern sector of the convection (between 300 and $700 \mathrm{~km}$ ) (figure not shown) and a reduction $\left(<17.5 \mathrm{~m} \mathrm{~s}^{-1}\right.$ at $150 \mathrm{hPa}$ ) around and at the rear of the MCS2 (up to $400 \mathrm{~km}$ ). An examination of the $150 \mathrm{hPa}$ wind speed Hovmüller diagram indicates that the core of the TEJ propagates westwards, staying in phase with the MCS.

\subsection{Distribution and tracking of rain events}

The intensity of rain events has a major impact on surface and hydrological processes such as runoff, infiltration, soil erosion and floods, especially over the Sahel, where intense showers can 


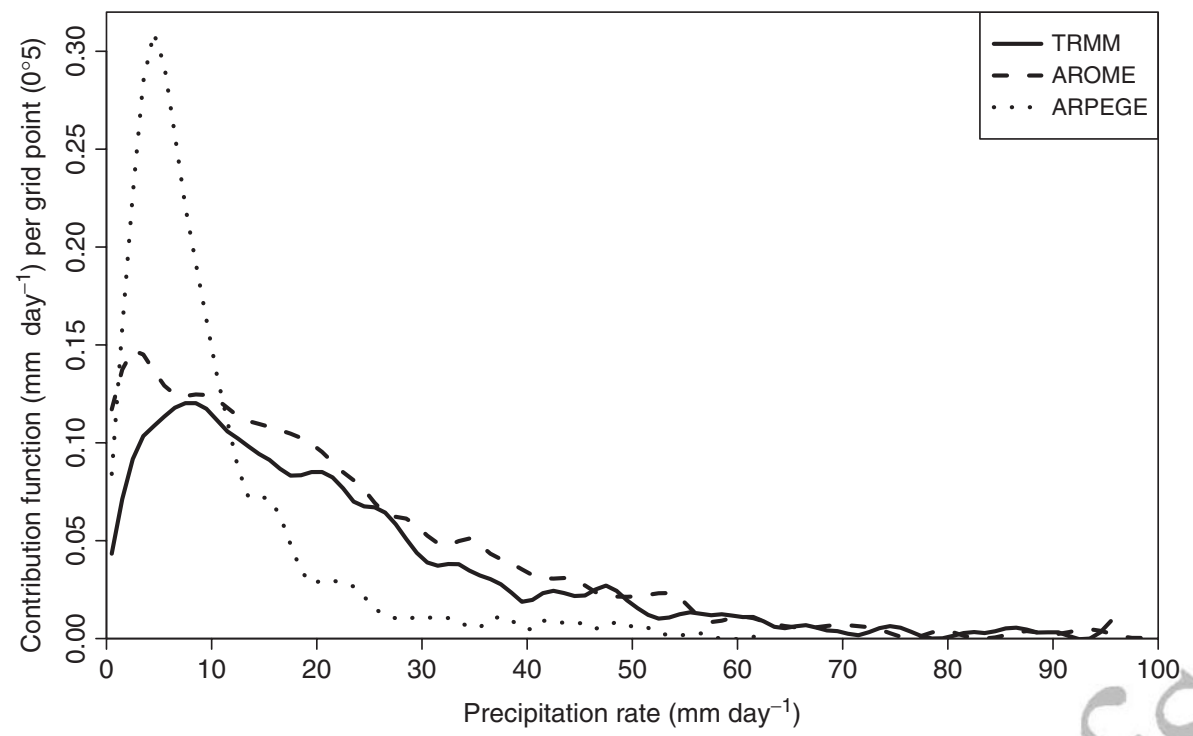

Figure 14. Daily (0000-0000 UTC) rain contribution function for the TRMM-3B42 product (black curve), the AROME $144 \mathrm{~h}$ forecast (dashed curve), and ARPEGE $6 \mathrm{~h}$ forecast (dotted curve) for a common $0.5^{\circ}$ grid and by class of $1 \mathrm{~mm} \mathrm{day}^{-1}$ ranging from 0 to $100 \mathrm{~mm} \mathrm{day}^{-1}$. Data are averaged over the $23-27$ July 2006 period and in the $\left(0-20^{\circ} \mathrm{N}, 15^{\circ} \mathrm{W}-20^{\circ} \mathrm{E}\right)$ domain.

have dramatic impacts. Figure 14 displays the distribution of the rain contribution to the daily precipitation intensity. To allow comparison between simulations at different resolutions with the TRMM-3B42 product, a common spatial $\left(0.5^{\circ}\right)$ and temporal (daily) resolution has been chosen. AROME correctly reproduces the distribution provided by satellite estimates, with a tendency to overestimate all regimes. In contrast, ARPEGE overestimates the number of low rain rates that are associated with isolated convection, whereas it underestimates the number of intense rain rate characteristics above the Sahel. These results are confirmed by the median cumulative rainfall: the AROME median fits the TRMM one $\left(17 \mathrm{~mm} \mathrm{day}^{-1}\right)$ while the ARPEGE median is largely underestimated $\left(7 \mathrm{~mm} \mathrm{day}^{-1}\right)$. The integral of each curve gives the daily mean precipitation. As already seen on Figure 8, AROME overestimates rainfall $\left(4.3 \mathrm{~mm} \mathrm{day}^{-1}\right)$ by about one quarter $(+26 \%)$ as compared with TRMM (3.4 $\left.\mathrm{mm}^{-1 a y}{ }^{-1}\right)$, whereas ARPEGE mean rainfall is correct $\left(3.3 \mathrm{~mm} \mathrm{day}^{-1}\right)$ at this scale.

To better evaluate the AROME and ARPEGE skills in forecasting the MCSs, we now compare the tracking method based on simulated rain with the GSMaP satellite-based rainfall estimates, as explained in section 2.2. Figure $15(\mathrm{a})-(\mathrm{c})$ display the trajectories of MCSs lasting more than $6 \mathrm{~h}$ over the 25-27 July 2006 period, with continental initiations. The tracking from the AROME simulated rain (Figure 15(b)) is in good agreement with the one from the GSMaP rainfall (Figure 15(a)) in terms of location, speed, life span and number of systems. In both trackings, the MCS1 and MCS2 trajectories passing over Niamey at the beginning and the end of 25 July respectively are captured. The simulated and the 'observed' trajectories of the MCS2 are very similar and cover a distance of about $2000 \mathrm{~km}$ from west of Lake Chad to east of Guinea within about $50 \mathrm{~h}$. The simulated trajectory of the MCS1 passes a little too far south at Niamey as compared to the 'observed' trajectory, as already shown by the TRMM-3B42 satellite-based rainfall (Figure 10(b)). Longlived and fast-moving MCSs mainly occur in the Sahel band $\left(10-15^{\circ} \mathrm{N}\right)$, where the environmental conditions (CAPE, strong easterly shear between the monsoon and the AEJ, midlevel dry air) are favourable to the formation of intense density currents that help to structure fast-moving squall-line-type MCSs (Barnes and Sieckman, 1984; Rotunno et al., 1988; Lafore and Moncrieff, 1989). These MCSs can cover great distances and move westward. In contrast, to the south, MCSs move more slowly and have a shorter duration, so few MCSs can last more than $6 \mathrm{~h}$. These results are consistent with several studies showing that the long-lasting rainfall episodes are supported by significant CAPE and vertical shear (Hodges and Thorncroft, 1997; Fink et al., 2006; Mohr and Thorncroft, 2006; Thorncroft et al., 2008). MCSs simulated by ARPEGE have a shorter duration and move more slowly, so very few can be detected on Figure 15(c).

The tracking approach provides information useful for improving knowledge of the characteristics of each observed and simulated MCS, which can be studied statistically to characterize the forecast skill and behaviour of each model. Figure 16 illustrates the mean diurnal cycle of the continental initiation and dissipation of MCSs over the period of 23-28 July 2006. The diurnal cycles simulated by AROME are in good agreement with the ones deduced from GSMaP rainfall estimates. When all systems are considered, GSMaP and AROME exhibit a marked diurnal cycle of initiation (Figure 16(a)), maximum in the afternoon and minimum in the morning. In contrast, dissipation (Figure 16(b)) is minimum at noon and maximum in the evening with a decrease during the night. The time difference between the initiation and dissipation maxima gives a crude estimation of the most frequent MCS duration $(\sim 6 \mathrm{~h})$. When only systems lasting more than $6 \mathrm{~h}$ are considered, the number of events decreases as expected (half), and the initiation occurs a little earlier in the afternoon (Figure 16(c)). The diurnal cycle of dissipation is less marked than that of initiation but more dissipation occurs during the night and the morning (Figure 16(d)). Mathon and Laurent (2001) provided an eight-year, high-resolution climatology of Sahelian MCSs based on tracking infrared images with a time resolution of $0.5 \mathrm{~h}$ and spatial resolution $5 \mathrm{~km}$. Their results (their Fig. 11(a)) show that MCS initiations exhibit a large diurnal cycle with a maximum between 1600 and 1700 LST and that MCS dissipations occur around 2100 LST. ARPEGE shows less intense rain events than AROME. Their triggering occurs earlier, between 1200 and 1500 UTC, not later in the afternoon (Figure 16(a)), and dissipates in the afternoon (1500-1800 UTC), resulting in a shorter mean duration $(\sim 3 \mathrm{~h})$. Events with durations longer than $6 \mathrm{~h}$ are rare during this short period and cannot be documented in terms of diurnal cycle (Figure 16(c) and (d)).

In short, when comparing with the satellite-based rainfall estimates, it appears that ARPEGE is unable to represent the high spatial and temporal variability of precipitation associated with MCSs over the Sahel, although the mean rain is correctly simulated. On the other hand, a CRM such as AROME correctly retrieves the spatial and temporal precipitation variability, but with some overestimation of its mean value. Thus, high resolution brings substantial progress in the representation of convection and associated precipitation patterns over West Africa as compared with models at lower resolution using a convective scheme.
19 


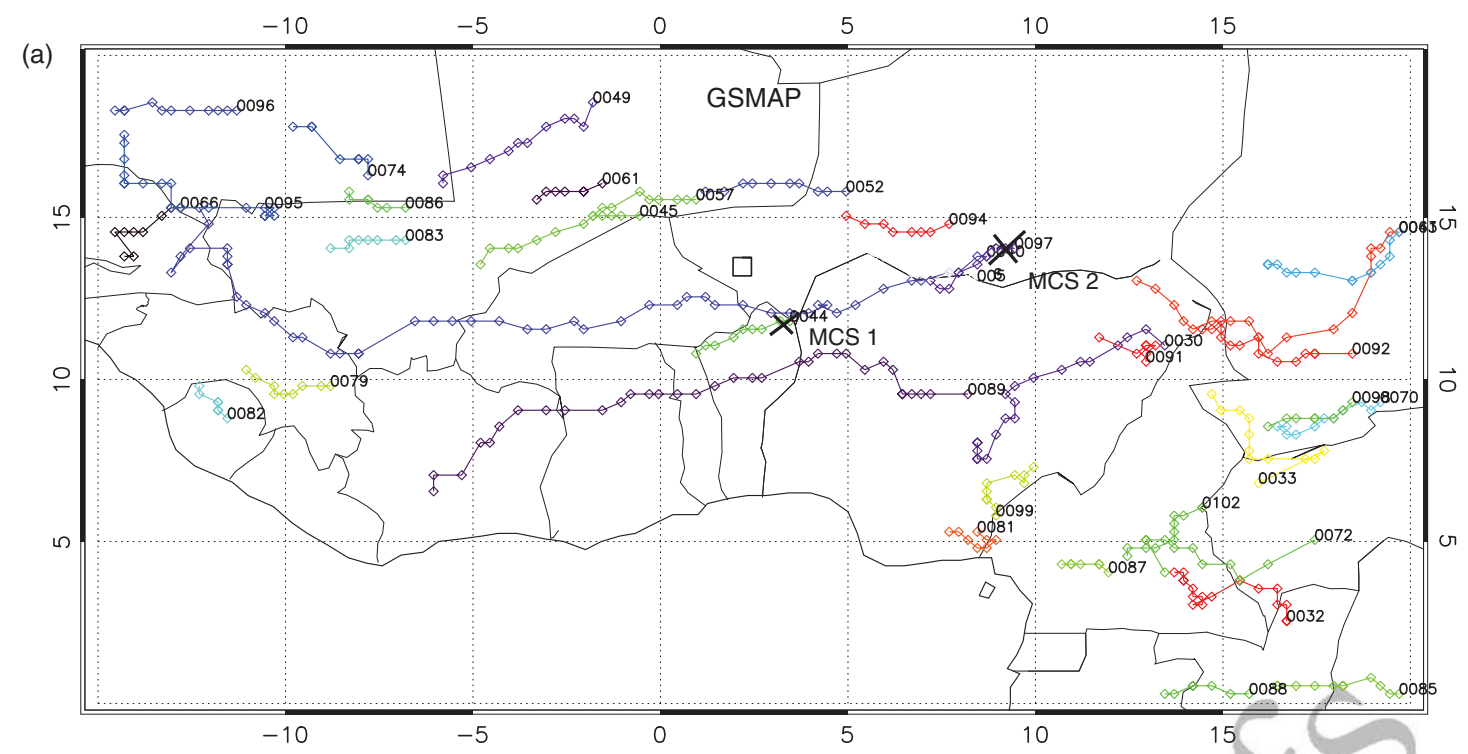

(a)

(1)

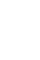

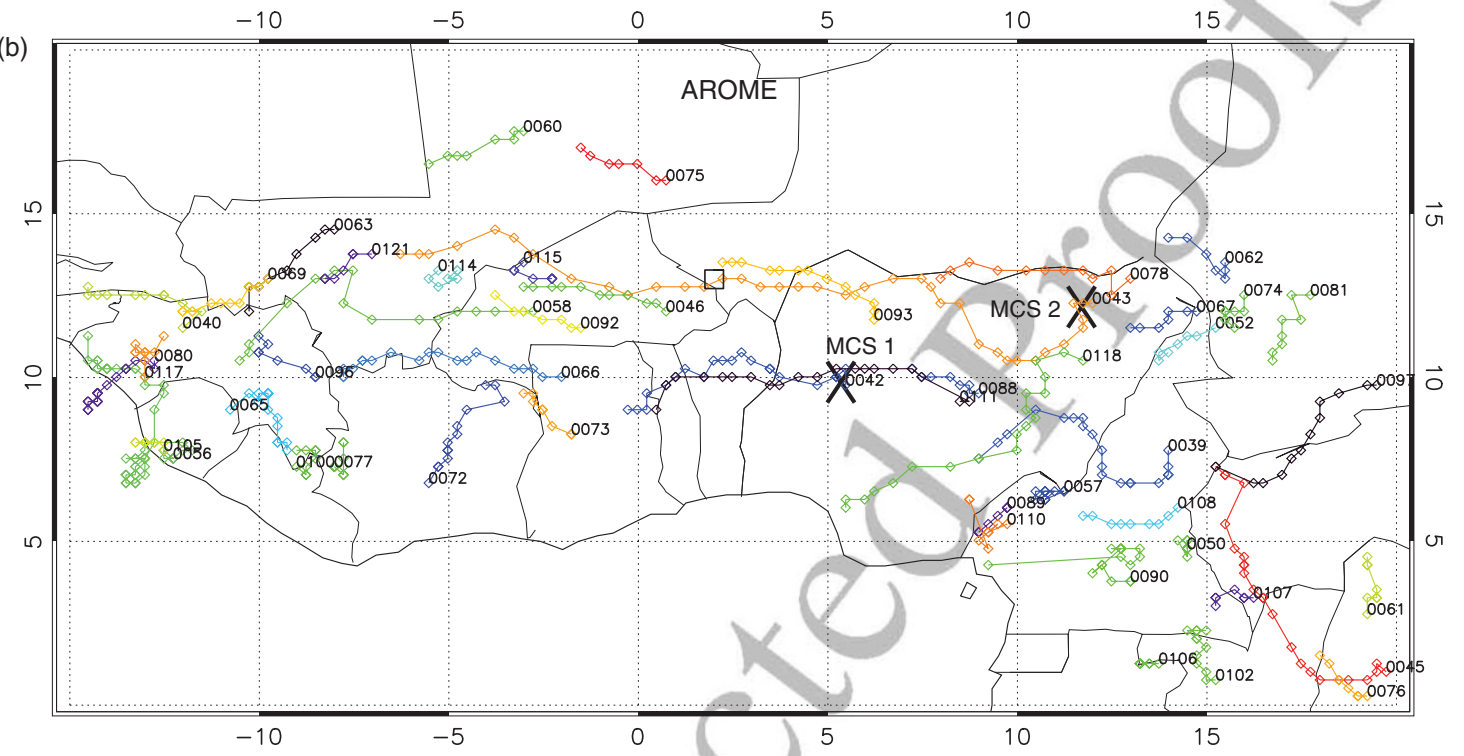

(c)

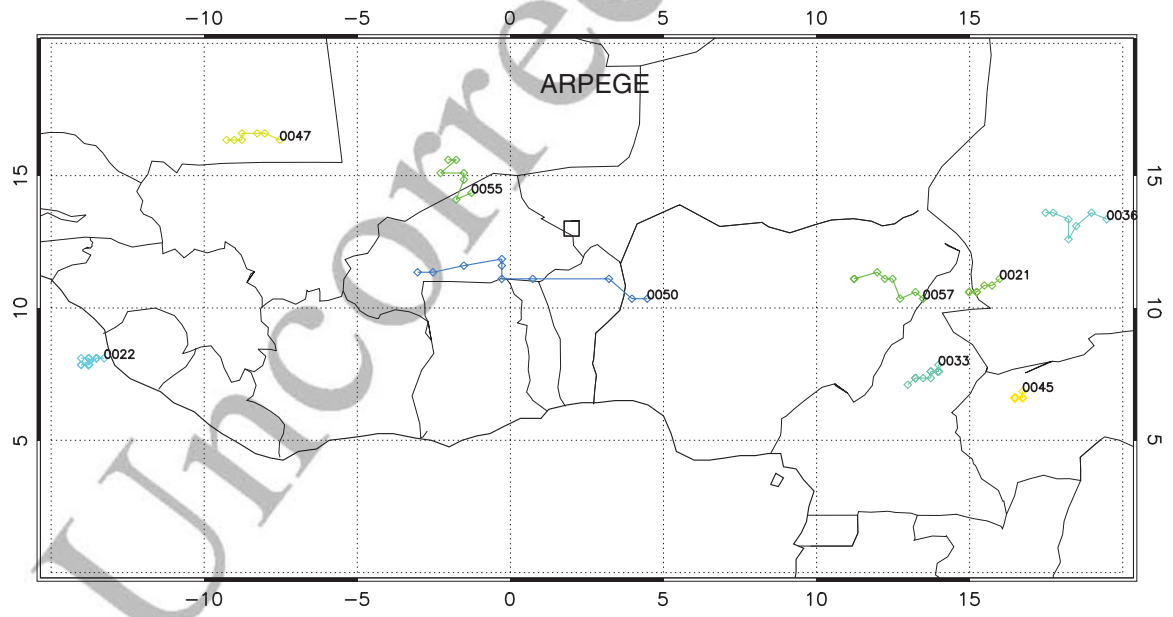

Figure 15. Trajectory of MCSs with lifetimes longer than $6 \mathrm{~h}$ and with continental initiation over the $25-27$ July 2006 period. The tracking is derived from the pattern of rainfall heavier than $2 \mathrm{~mm} \mathrm{~h}^{-1}$ (a) aggregated on a $0.25^{\circ}$ horizontal grid for satellite-based precipitation GSMaP, (b) on a $0.25^{\circ}$ grid for the AROME simulation, and (c) on a $0.25^{\circ}$ grid for the ARPEGE CY $33+$ A simulation. Each diamond indicates the location of the MCS at an hourly frequency. The tracking threshold is set to $2 \mathrm{~mm} \mathrm{~h}^{-1}$. The label added at the start of the trajectory corresponds to its number in the tracking file.

\section{Conclusion and discussion}

The major aim of this article was to investigate the forecasting potential of the French high-resolution NWP regional model AROME during the West African monsoon (WAM) season. We ran experiments over a large part of West Africa over a 6-day period well documented by the AMMA 2006 field campaign (Barthe et al., 2010). The spatial distribution of the daily mean precipitation shows strong similarities between the AROME forecasts and the satellite-derived precipitation TRMM-3B42, with good location of the ITCZ. The simulations produce a realistic scenario with the passage of two westward, fast-moving 60 MCSs coupled with an intense AEW and a deep monsoon surge. 61 AROME shows its ability to forecast long-lived MCSs and AEWs. 62 The daily rainfall distribution shows the capacity of AROME 63 to correctly reproduce all regimes, from light rains to the largest 64 
(a)

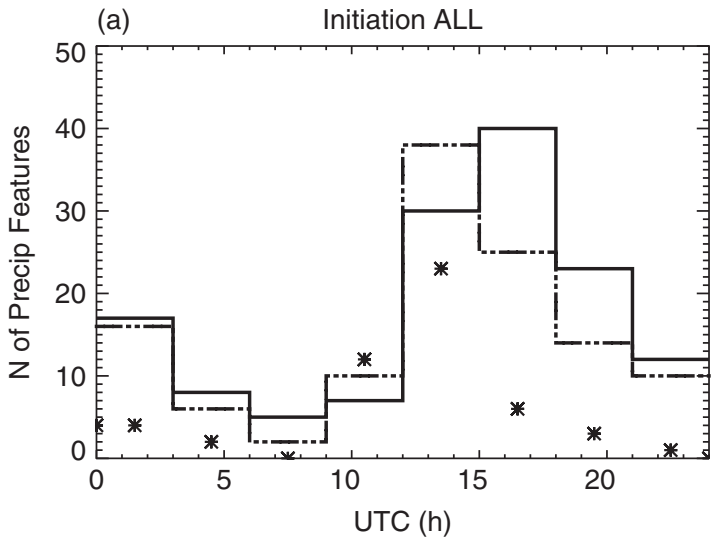

(c)

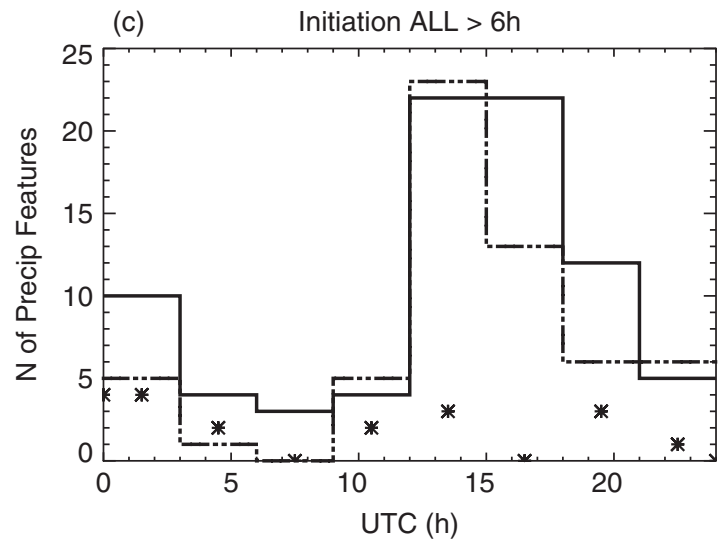

(b)

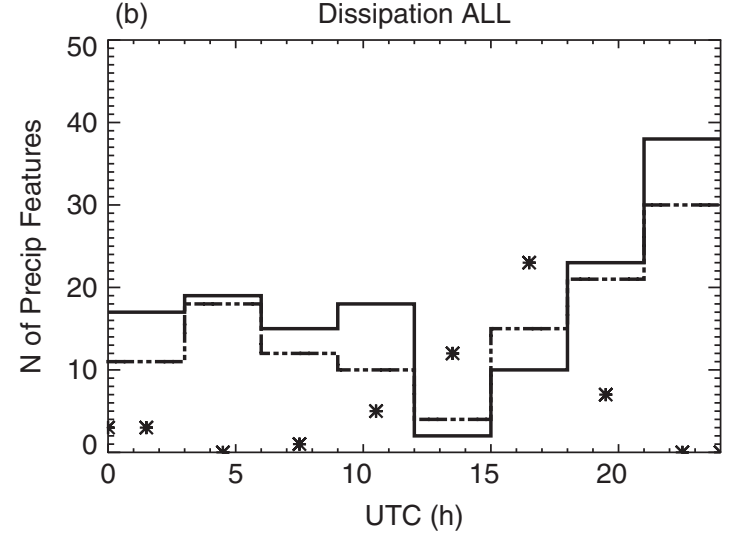

(d)

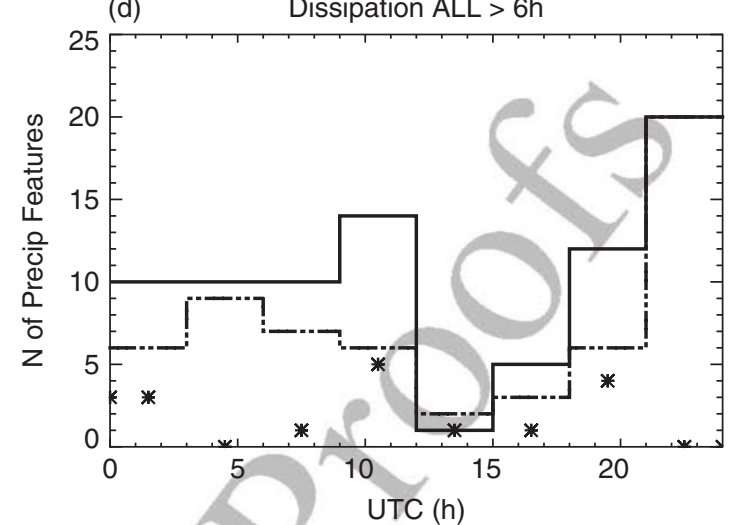

1

2

3

4

5

6

7

8

9

10

11

12

13

14

15

16

17

18

19

20

21

22

23

24

25

26

27

28 29

30

32

33

34 35 36 


\section{Acknowledgement}

The authors are grateful to the anonymous reviewers for their thoughtful and useful comments on the original manuscript. We also kindly thank all contributors to the datasets used in this study, which were produced as part of the AMMA campaign. Based on a French initiative, AMMA was built by an international scientific group and is currently funded by a large number of agencies, especially from France, United Kingdom, USA and Africa. We are grateful to F. Favot, P. Peyrillé, D. Ricard, S. 10 Malardel, V. Pedinotti, V. Matthiot, G. Beffrey, and J. Aublanc 11 for their assistance with computing facilities. The first author is 12 also grateful for the NCL facilities developed by the University 13 Corporation for Atmospheric Research (UCAR), including its 14 programs, the National Center for Atmospheric Research (NCAR) 15 and its laboratories.

\section{References}

Agusti-Panadera A, Beljaard A, Cardinali C, Genkova I, Thorncroft CD. 2010. Impact of assimilating AMMA soundings on ECMWF analyses and forecasts. Weather and Forecasting 25: 1142-1160.

Ali A, Lebel T, Amani A. 2005. Rainfall estimation in the Sahel. Part I: error function. J. Appl. Meteorol. 44: 1691-1706.

Bain CL, Parker DJ, Dixon N, Fink AH, Taylor CM, Brooks B, Milton SF. 2011. Anatomy of an observed African easterly wave in July 2006. Q. J. R. Meteorol. Soc. 137: 923-933.

Barnes G, Sieckman K. 1984. The environment of fast and slow moving tropical mesoscale convective cloud lines. Mon. Weather Rev. 112: 1782-1794.

Barthe C, Asencio N, Lafore J-P, Chong M, Campistron B, Cazenave F. 2010. Multiscale analysis of the 25-27 July 2006 convective period over Niamey: comparison between Doppler radar observations and simulations. Q. J. R. Meteorol. Soc. 136: 190-208.

Bauer P. 2009. 4D-Var assimilation of MERIS total column water-vapour retrievals over land. Q. J. R. Meteorol. Soc. 135: 1852-1862.

Bechtold P, Bazile E, Guichard F, Mascart P, Richard E. 2001. A mass-flux convection scheme for regional and global models. Q. J. R. Meteorol. Soc. 127: $869-886$

Berry G, Thorncroft CD. 2005. Case study of an intense African easterly wave. Mon. Weather Rev. 133: 752-766.

Berry G, Thorncroft CD, Hewson T. 2006. African easterly waves during 2004 - Analysis using objective techniques. Mon. Weather Rev. 135: 1251-1267.

Birch CE, Parker DJ, O’Leary A, Marsham JH, Taylor CM, Harris PP, Lister GMS. 2012. Impact of soil moisture and convectively generated waves on the initiation of a West African mesoscale convective system. Q. J. R. Meteorol. Soc. On-line version, DOI: 10.1002/qj.2062.

Bock O, Nuret M. 2009. Verification of NWP model analyses and radiosonde humidity data with GPS precipitable water vapor estimates during AMMA. Weather and Forecasting 24: 1085-1101.

Bock O, Bouin MN, Walpersdorf A, Lafore J-P, Janicot S, Guichard F, Agusti-Panareda A. 2007. Comparison of ground-based GPS precipitable water vapour to independent observations and NWP model reanalyses over Africa. Q. J. R. Meteorol. Soc. 133: 2011-2027.

Boone A, Decharme B, Guichard F, de Rosnay P, Balsamo G, Beljaars A, Chopin F, Orgeval T, Polcher J, Delire C, Ducharne A, Gascoin S, Grippa M, Jarlan L, Kergoat L, Mougin E, Gusev Y, Nasonova O, Harris P, Taylor C, Norgaard A, Sandholt I, Ottlé C, Poccard-Leclercq I, Saux-Picart S, Xue YK. 2009. The AMMA Land Surface Model Intercomparison Project (ALMIP). Bull. Am. Meteorol. Soc. 90: 1865-1880.

Bougeault P. 1985. A simple parameterization of the large-scale effects of cumulus convection. Mon. Weather Rev. 113: 2108-2121.

Bryan GH, Wyngaard JC, Fritsch JM. 2003. Resolution requirements for the simulation of deep moist convection. Mon. Weather Rev. 131: 2394-2416.

Bubnová R, Hello G, Bénard P, Geleyn J-F. 1995. Integration of the fully elastic equations cast in the hydrostatic pressure terrain-following coordinate in the framework of the ARPEGE/Aladin NWP system. Mon. Weather Rev. 123: $515-535$.

Cappelaere B, Descroix L, Lebel T, Boulain N, Ramier D, Laurent J-P, Le Breton E, Mamadou I, Boubkraoui S, Bouzou Moussa I, Favreau G, Issoufou HBA, Nazoumou Y, Quantin G, Chaffard V, Ottlé C. 2009. The AMMA-CATCH experiment in the cultivated Sahelian area of southwest Niger - Strategy, implementation, site description, main results. J. Hydrol. 375: 34-51.

Courtier P, Thépaut J-N, Hollingsworth A. 1994. A strategy for operational implementation of 4D-Var, using an incremental approach. Q. J. R. Meteorol. Soc. 120: 1367-1387.

Couvreux F, Guichard F, Bock O, Campistron B, Lafore J-P, Redelsperger J-L. 2010. Synoptic variability of the monsoon flux over West Africa prior to the onset. Q. J. R. Meteorol. Soc. 136: 159-173, DOI: 10.1002/qj.473.

Cuesta J, Lavaysse C, Flamant C, Mimouni M, Knippertz P. 2010. Northward bursts of the West African monsoon leading to rainfall over the Hoggar Massif, Algeria. Q. J. R. Meteorol. Soc. 136: 174-189, DOI: 10.1002/qj.439.

Cuxart J, Bougeault P, Redelsberger J-L. 2000. A turbulence scheme allowing for mesoscale and large-eddy simulations. Q. J. R. Meteorol. Soc. 126: 1-30.
Diongue A, Lafore J-P, Redelsperger J-L, Roca R. 2002. Numerical study of a Sahelian synoptic weather system: initiation and mature stages of convection and its interactions with the large-scale dynamics. Q. J. R. Meteorol. Soc. 128: $1899-1927$.

Ducrocq V, Bougeault P. 1995. Simulations of an observed squall line with a meso-beta scale hydrostatic model. Weather and Forecasting 10: 380-399.

Faccani C, Rabier F, Fourié N, Agusti A, Moll P, Lafore J-P, Nuret M, Hdidou FZ, Bock O. 2009. The impact of the AMMA radiosonde data on the French global assimilation and forecast system. Weather and Forecasting 24: $1264-1286$.

Fink AH, Vincent DG, Ermert V. 2006. Rainfall types in the West African Sudanian Zone during the summer monsoon 2002. Mon. Weather Rev. 134: 2143-2164.

Fiolleau T. 2010. 'Cycle de vie des systèmes convectifs de mousson dans les régions tropicales: préparation de la mission Megha-Tropiques', $\mathrm{PhD}$ thesis, 213 pp. Université Paris 6 Pierre et Marie Curie.

Fiolleau T, Roca R. 2013. An algorithm for the detection and tracking of tropical mesoscale convective systems using infrared images from geostationary satellite. IEEE Trans. Geosci. Remote Sensing 51: 4302-4315.

Fouquart Y, Bonnel B. 1980. Computations of solar heating of the Earth's atmosphere: a new parameterization. Beitr. Phys. Atmos. 53: 35-62.

Gosset M, Viarre J, Quantin G, Alcoba M. 2013. Evaluation of several rainfall products used for hydrological applications over West Africa using two high-resolution gauge networks. Q. J. R. Meteorol. Soc. 139: 923-940.

Guichard F, Asencio N, Peugeot C, Bock O, Redelsperger J-L, Cui XF, Garvert M, Lamptey B, Orlandi E, Sander J, Fierli F, Gaertner MA, Jones SC, Lafore J-P, Morse A, Nuret M, Boone A, Balsamo G, de Rosnay P, Decharme B, Harris PP, Bergès J-C. 2010. An intercomparison of simulated rainfall and evapotranspiration associated with a mesoscale convective system over West Africa. Weather and Forecasting 25: 37-60.

Hall NJM, Kiladis GN, Thorncroft CD. 2006. Three-dimensional structure and dynamics of African easterly waves. Part II: dynamical modes. J. Atmos. Sci. 63: $2231-2245$

Hodges KI, Thorncroft CD. 1997. Distribution and statistics of African mesoscale convective weather systems based on the ISCCP Meteosat imagery. Mon. Weather Rev. 125: 2821-2837.

Huffman GJ, Adler RF, Bolvin DT, Gu G, Nelkin EJ, Bowman KP, Hong Y, Stocker EF, Wolff DB. 2007. The TRMM Multisatellite Precipitation Analysis (TMPA): quasiglobal, multiyear, combined-sensor precipitation estimates at fine scales. J. Hydrometeorol. 8: 3855, DOI: 10.1175/JHM560.

Janicot S, Thorncroft CD, Ali A, Asencio N, Berry G, Bock O, Bourles B, Caniaux G, Chauvin F, Deme A, Kergoat L, Lafore JP, Lavaysse C, Lebel T, Marticorena B, Mounier F, Nedelec P, Redelsperger JL, Ravegnani F, Reeves CE, Roca R, de Rosnay P, Schlager H, Sultan B, Tomasini M, Ulanovsky A. 2008. Large-scale overview of the summer monsoon over West Africa during the AMMA field experiment in 2006. Ann. Geophys. 26: 2569-2595.

Janicot S, Caniaux G, Chauvin F, de Coëtlogon G, Fontaine B, Hall N, Kiladis G, Lafore J-P, Lavaysse C, Lavender SL, Leroux S, Marteau R, Mounier F, Philippon N, Roehrig R, Sultan B, Taylor CM. 2011. Intraseasonal variability of the West African monsoon. Atmos. Sci. Lett. 12: 58-66, DOI: 10.1002/asl.280.

Jobard I, Chopin F, Berges JC, Roca R. 2011. An intercomparison of 10-day satellite precipitation products during West African monsoon. Int. J. Remote Sensing 32: 2353-2376.

Karbou F, Gerard E, Rabier F. 2010a.. Global 4DVar assimilation and forecast experiments using AMSU observations over land. Part I: impacts of various land surface emissivity parameterizations. Weather and Forecasting 25: 5-19.

Karbou F, Rabier F, Lafore J-P, Redelsperger J-L, Bock O. 2010b.. Global 4DVar assimilation and forecast experiments using AMSU observations over land. Part II: impacts of assimilating surface-sensitive channels on the African monsoon during AMMA. Weather and Forecasting 25: 20-36.

Klüpfel V, KalthoffN, Gantner L, Kottmeier C. 2011. Evaluation of soil moisture ensemble runs to estimate precipitation variability in convection-permitting model simulations for West Africa. Atmos. Res. 101: 178-193.

Klüpfel V, Kalthoff N, Gantner L, Taylor CM. 2012. Convergence zones and their impact on the initiation of a mesoscale convective system in West Africa. Q. J. R. Meteorol. Soc. 138: 950-963.

Kocha C, Tulet P, Lafore J-P, Flamant C. 2013. The importance of the diurnal cycle of aerosol optical depth in West Africa. Geophys. Res. Lett. 40: 785-790.

Laing AG, Carbone RE, Levizzani V, Tuttle J. 2008. The propagation and diurnal cycles of deep convection in northern tropical Africa. Q. J. R. Meteorol. Soc. 134: 93-109.

Laing AG, Trier SB, Davis CA. 2012. Numerical simulation of episodes of organized convection in tropical northern Africa. Mon. Weather Rev. 140: $2874-2886$.

Lafore J-P, Moncrieff MW. 1989. A numerical investigation of the organization and interaction of the convective and stratiform regions of tropical squall lines. J. Atmos. Sci. 46: 521-544.

Lafore J-P, Stein J, Asencio N, Bougeault P, Ducrocq V, Duron J, Fischer C, Héreil P, Mascart P, Masson V, Pinty J-P, Redelsperger J-L, Richard E, Vilà-Guerau de Arellano J. 1998. The Meso-NH atmospheric simulation system. Part I: adiabatic formulation and control simulations. Ann. Geophys. 16: $90-109$.

Lean HW, Clark PA, Dixon M, Roberts NM, Fitch A, Forbes R, Halliwell C. 2008. Characteristics of high-resolution versions of the Met Office Unified Model for forecasting convection over the United Kingdom. Mon. Weather Rev. 136: 3408-3424. 4

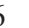
9 
Rabier F, Järvinen H, Klinker E, Mahfouf J-F, Simmons A. 2000. The ECMWF operational implementation of four-dimensional variational assimilation. I: experimental results with simplified physics. Q. J. R. Meteorol. Soc. 126: $1143-1170$. Thest Risk Assess. 14: 275-295.

LeMone M, Zipser E, Trier S. 1998. The role of environmental shear and thermodynamic conditions in determining the structure and evolution of mesoscale convective systems during TOGA-COARE. J. Atmos. Sci. 55: $3493-3518$.

Lothon M, Said F, Lohou F, Campistron B. 2008. Observations of the diurnal cycle in the low troposphere of West Africa. Mon. Weather Rev. 136 3477-3500.

Marsham JH, Knippertz P, Dixon NS, Parker DJ, Lister GMS. 2011. The importance of the representation of deep convection for modeled dustgenerating winds over West Africa during summer. Geophys. Res. Lett. 38 L16803, DOI: 10.1029/2011GL048368.

Mathon V, Laurent H. 2001. Life cycle of Sahelian mesoscale convective cloud systems. Q. J. R. Meteorol. Soc. 127: 37-406.

Mathon V, Laurent H, Lebel T. 2002. Mesoscale convective system rainfall in the Sahel. J. Appl. Meteorol. 41: 1081-1092.

Mlawer EJ, Taubman SJ, Brown P, Iacono MJ, Clough SA. 1997. Radiative transfer for inhomogeneous atmospheres: RRTM, a validated correlated-k model for the longwave. J. Geophys. Res. 102: 16663-16682.

Mohr KI, Thorncroft CD. 2006. Intense convective systems in West Africa and their relationship to the African easterly jet. Q. J. R. Meteorol. Soc. 132: $163-176$.

Noilhan J, Mahfouf J-F. 1996. The ISBA land surface parameterisation scheme. Global and Planetary Change 13: 145-159.

Nuret M, Lafore J-P, Gouget V, Ducrocg V. 2005. Mesoscale analysis and impact on simulation of IOP14 of the MAP experiment. Q. J. R. Meteorol. Soc. 131: 2769-2793.

Omotosho JB. 1985. The separate contributions of squall lines thunderstorms and the monsoon to the total rainfall in Nigeria. J. Climatol. 5: $543-552$.

Parker DJ, Burton RR, Diongue-Niang A, Ellis RJ, Felton M, Taylor CM Thorncroft CD, Bessemoulin P, Tompkins AM. 2005. The diurnal cycle of the West African monsoon circulation. Q. J. R. Meteorol. Soc. 131 2839-2860.

Parker DJ, Fink AH, Janicot S, Ngamini JB, Douglas M, Afiesimama E, AgustiPanareda A, Beljaars A, Dide F, Diedhiou A, Lebel T, Polcher J, Redelsperger J-L, Thorncroft CD, Wilson GA. 2008. The AMMA radiosonde program and its implications for the future of atmospheric monitoring over Africa. Bull. Am. Meteorol. Soc. 89: 1015-1027.

Pearson KJ, Hogan RJ, Allan RP, Lister GMS, Holloway CE. 2010. Evaluation of the model representation of the evolution of convective systems using satellite observations of outgoing longwave radiation. J. Geophys. Res. 115: D20206, DOI: 10.1029/2010JD014265.

Pedinotti V, Boone A, Decharme B, Crétaux JF, Mognard N, Panthou G, Papa F, Tanimoun BA. 2012. Evaluation of the ISBA-TRIP continental hydrologic system over the Niger basin using in situ and satellite derived datasets. Hydrol. Earth Syst. Sci. 16: 1745-1773.

Pergaud J, Masson V, Malardel S, Couvreux F. 2009. A parameterization of dr thermals and shallow cumuli for mesoscale numerical weather prediction. Boundary-Layer Meteorol. 132: 83-106.

Peyrillé P, Lafore J-P. 2007. An idealized two-dimensional framework to study the West African monsoon. Part II: large-scale advection and the diurna cycle. J. Atmos. Sci. 64: 2783-2803.

Pierre C, Bergametti G, Marticorena B, Mougin E, Lebel T, Ali A. 2011. Pluriannual comparisons of satellite-based rainfall products over the Sahelian belt for seasonal vegetation modeling. J. Geophys. Res. 116: D18201, DOI: 10.1029/2011JD016115.

Pinty J-P, Jabouille P. 1998. A mixed-phased cloud parameterization for use in a mesoscale non-hydrostatic model: simulations of a squall line and of orographic precipitation. Preprints, Conference on Cloud Physics: 217-220 American Meteorological Society: Everett, WA.

Poan DE, Roehrig R, Couvreux F, Lafore J-P. 2012. West African monsoon intraseasonal variability: a precipitable water perspective. J. Atmos. Sci. 70: $1035-1052$.
Redelsperger J-L, Thorncroft CD, Diedhiou A, Lebel T, Parker DJ, Polcher J. 2006. African monsoon multidisciplinary analysis: an international research project and field campaign. Bull. Am. Meteorol. Soc. 87: 1739-1746.

Reed RD, Nordquist DC, Recker EE. 1977. The structure and properties of African wave disturbances observed during phase III of GATE. Mon. Weather Rev. 105: 317-333.

Roca R, Chambon P, Jobard I, Kirstetter P-E, Gosset M, Bergès JC. 2010. Comparing satellite and surface rainfall products over West Africa at meteorologically relevant scales during the AMMA campaign using error estimates. J. Appl. Meteorol. Clim. 49: 715-731.

Rodríguez-Fonseca B, Janicot S, Mohino E, Losada T, Bader J, Caminade C, Chauvin F, Fontaine B, García-Serrano J, Gervois S, Joly M, Polo I, Ruti P, Roucou P, Voldoire A. 2011. Interannual and decadal SST-forced responses of the West African monsoon. Atmos. Sci. Lett. 12: 67-74, DOI: 10.1002/asl.308.

Roehrig R, Bouniol D, Guichard F, Hourdin F, Redelsperger J-L. 2013. The present and future of the West African monsoon: a process-oriented assessment of CMIP5 simulations along the AMMA transect. J. Climate 26: 6471-6505.

Rotunno R, Klemp JB, Weisman ML. 1988. A theory for strong, longlived squall lines. J. Atmos. Sci. 45: 463-485.

Sane Y, Bonazzola M, Rio C, Chambon P, Fiolleau T, Musat I, Hourdin F, Roca R, Grandpeix J-Y, Diedhiou A. 2012. An analysis of the diurnal cycle of precipitation over Dakar using local rain-gauge data and a general circulation model. Q. J. R. Meteorol. Soc. 138: 2182-2195, DOI: 10.1002/qj.1932.

Seity Y, Brousseau P, Malardel S, Hello G, Bénard P, Bouttier F, Lac C, Masson V. 2011. The AROME-France convective scale operational model. Mon. Weather Rev. 139: 976-991.

Smull BF, Houze RA Jr. 1987. Rear inflow in squall lines with trailing stratiform precipitation. Mon. Weather Rev. 115: 2869-2889.

Taylor CM, Gounou A, Guichard F, Harris PP, Ellis RJ, Couvreux F, De Kauwe M. 2011. Frequency of Sahelian storm initiation enhanced over mesoscale soil-moisture patterns. Nat. Geosci. 4: 430-344, DOI: 10.1038/NGEO1173.

Taylor KE. 2001. Summarizing multiple aspects of model performance in a single diagram. J. Geophys. Res. 106: 7183-7192.

Thorncroft CD, Hoskins BJ. 1994a.. An idealized study of African easterly waves. Part I: a linear view. Q. J. R. Meteorol. Soc. 120: 953-982.

Thorncroft CD, Hoskins BJ. 1994b.. An idealized study of African easterly waves. Part II: a nonlinear view. Q. J. R. Meteorol. Soc. 120: 983-1015.

Thorncroft CD, Parker DJ, Burton RR, Diop M, Ayers JH, Barjat H, Devereau S, Diongue A, Dumelow R, Kindred DR, Price NM, Saloum M, Taylor CM, Tompkins AM. 2003. The Jet 2000 project: aircraft observations of the African easterly jet and African easterly waves. Bull. Am. Meteorol. Soc. 84: $337-351$.

Thorncroft CD, Hall NMJ, Kiladis GN. 2008. Three-dimensional structure and dynamics of African easterly waves. Part III: Genesis. J. Atmos. Sci. 65 : 3596-3607.

Tompkins AM, Diongue-Niang A, Parker DJ, Thorncroft CD. 2005. The African easterly jet in the ECMWF Integrated Forecast System: 4D-Var analysis. Q. J. R. Meteorol. Soc. 131: 2861-2885.

Torn RD. 2010. Ensemble-based sensitivity analysis applied to African easterly waves. Weather and Forecasting 25: 61-78.

Ushio T, Kubota T, Shige S, Okamoto K, Aonashi K, Inoue T, Takahashi N, approach to the Global Satellite Mapping of Precipitation (GSMaP) from combined passive microwave and infrared radiometric data. J. Meteorol. Soc. Jpn. 87A: $137-151$

Veersé F, Thépaut J-N. 1998. Multiple-truncation incremental approach for four-dimensional variational data assimilation. Q. J. R. Meteorol. Soc. 124: 1889-1908.

Weisman ML, Skamarock WC, Klemp JB. 1997. The resolution dependence of explicitly modeled convective systems. Mon. Weather Rev. 125: 527-548. Iguchi T, Kachi M, Oki R, Morimoto T, Kawasaki Z. 2009. A Kalman filter

\section{1} 2 3 4 5 6 7 9 
IMPORTANT NOTE: Please mark your corrections and answers to these queries directly onto the proof at the relevant place. Do NOT mark your corrections on this query sheet.

\section{Queries from the Copyeditor:}

AQ1 Please confirm if this year should be Thorncroft and Hoskins, 1994a or 1994b.

AQ2 Please define part labels (a) and (b) in caption for Figure 10.

AQ3 Please define part labels (a) and (b) in caption for Figure 11.

AQ4 Klüpfel et al., 2012 has not been cited in the text. Please indicate where it should be cited; or delete from the Reference List. 
Required software to e-Annotate PDFs: Adobe Acrobat Professional or Adobe Reader (version 7.0 or above). (Note that this document uses screenshots from Adobe Reader $\bar{X}$ )

The latest version of Acrobat Reader can be downloaded for free at: http://get.adobe.com/uk/readerl

Once you have Acrobat Reader open on your computer, click on the Comment tab at the right of the toolbar:

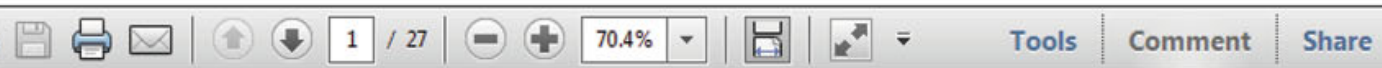

This will open up a panel down the right side of the document. The majority of tools you will use for annotating your proof will be in the Annotations section, pictured opposite. We've picked out some of these tools below:

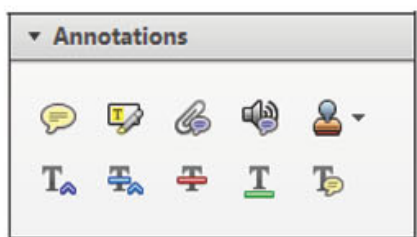

1. Replace (Ins) Tool - for replacing text.

Strikes a line through text and opens up a text box where replacement text can be entered.

How to use it

- Highlight a word or sentence.

- Click on the Replace (Ins) icon in the Annotations section.

- Type the replacement text into the blue box that appears.

Idard tramework for the analysis of $\mathrm{m}$ icy. Nevertheless, it alsoled to exog،

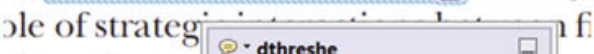
aber of comp 08/06/2011 15:58:17 is that the $\mathbf{s i}$, which led nain compo level, are ext ,

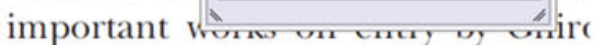
M henceforth) ${ }^{1}$ we onen the 'hlarl b

3. Add note to text Tool - for highlighting a section to be changed to bold or italic.

T) Highlights text in yellow and opens up a text box where comments can be entered.

\section{How to use it}

- Highlight the relevant section of text.

- Click on the Add note to text icon in the Annotations section.

- Type instruction on what should be changed regarding the text into the yellow box that appears.

namic responses of mark ups ent with the VAR evidence

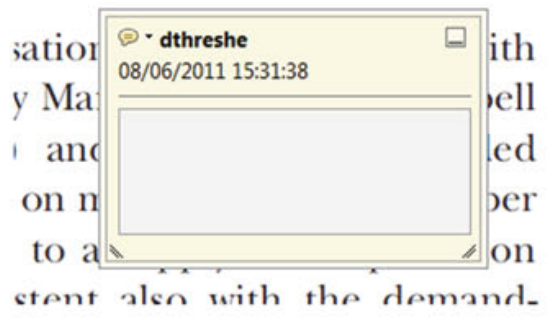

2. Strikethrough (Del) Tool - for deleting text.

Strikes a red line through text that is to be deleted.

How to use it

- Highlight a word or sentence.

- Click on the Strikethrough (Del) icon in the Annotations section.

there is no room for extra prohts as : ups are zero and the number of iet) values are not determined by Blanchard and Kivotaki (1987), sfect competition in general equilil ts of aggregate demand and supply lassical framework assuming monol sen an everonous number of firme

4. Add sticky note Tool - for making notes at specific points in the text.

Marks a point in the proof where a comment needs to be highlighted.

How to use it

- Click on the Add sticky note icon in the Annotations section.

- Click at the point in the proof where the comment should be inserted.

- Type the comment into the yellow box that appears.

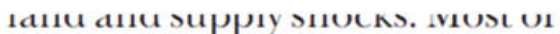

a@imil
numbe
dard fr:
cy. Nev
se of st
lber of threshe

is that the structure of the sectc. 
5. Attach File Tool - for inserting large amounts of text or replacement figures.

Inserts an icon linking to the attached file in the appropriate pace in the text.

\section{How to use it}

- Click on the Attach File icon in the Annotations section.

- Click on the proof to where you'd like the attached file to be linked.

- Select the file to be attached from your computer or network.

- Select the colour and type of icon that will appear in the proof. Click OK.

E N D

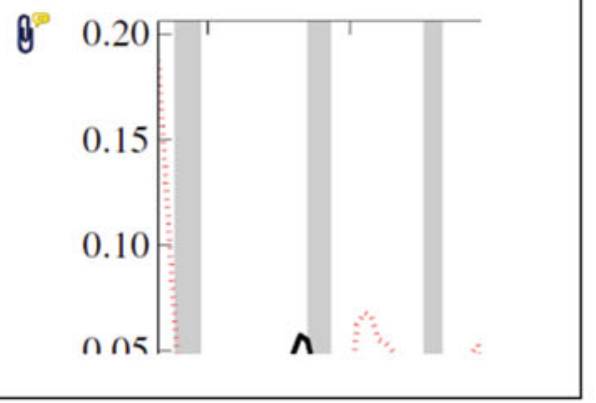

6. Add stamp Tool - for approving a proof if no corrections are required.

- Inserts a selected stamp onto an appropriate place in the proof.

How to use it

- Click on the Add stamp icon in the Annotations section.

- Select the stamp you want to use. (The Approved stamp is usually available directly in the menu that appears).

- Click on the proof where you'd like the stamp to appear. (Where a proof is to be approved as it is, this would normally be on the first page).

of the Dusiness cycie, starung with the on perfect competition, constant ret he otaki (1987), has introduced produc general equilibrium models with nomin:

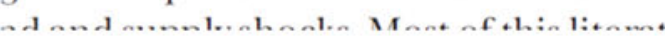

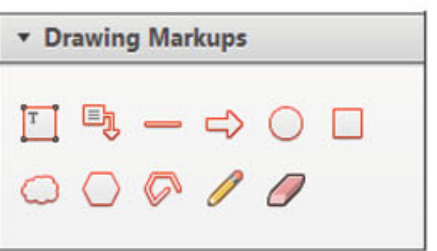

\section{How to use it}

- Click on one of the shapes in the Drawing Markups section.

- Click on the proof at the relevant point and draw the selected shape with the cursor.

- To add a comment to the drawn shape, move the cursor over the shape until an arrowhead appears.

- Double click on the shape and type any text in the red box that appears.
7. Drawing Markups Tools - for drawing shapes, lines and freeform annotations on proofs and commenting on these marks.

Allows shapes, lines and freeform annotations to be drawn on proofs and for comment to be made on these marks..

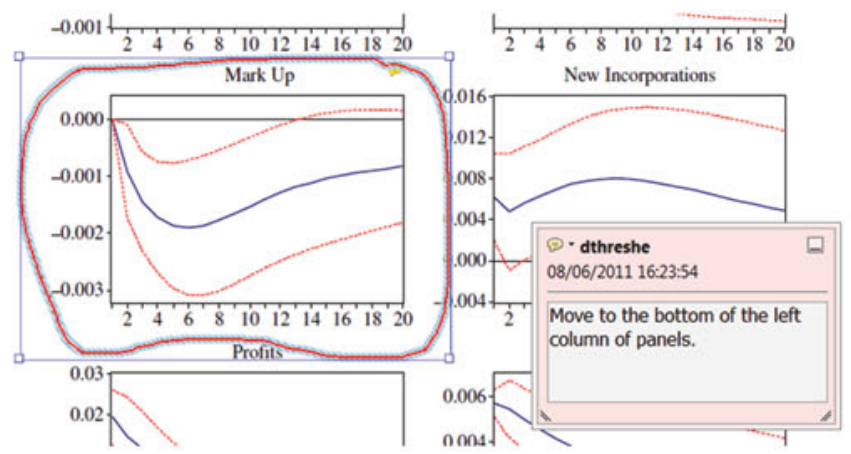

For further information on how to annotate proofs, click on the Help menu to reveal a list of further options:

\begin{tabular}{|l|l|l|l|l|l|}
\hline 2- ecoj_2384_CrxRev2_EV_19-Jul-10.pdf - Adobe Reader \\
\hline File Edit View Window
\end{tabular}

